\title{
Joanna Krenz
}

Instytut Orientalistyki, Uniwersytet im. Adama Mickiewicza w Poznaniu

\section{Przybrany ojciec. Czesław Miłosz w Chinach}

W 2012 roku mieszkająca obecnie w Stanach Zjednoczonych badaczka i tłumaczka Ming Di przeprowadziła ankietę wśród chińskich poetów. Pytała w niej m.in. o to, których dziesięciu zagranicznych autorów najbardziej wpłynęło na rozwój współczesnej poezji w Chinach. Aż ośmiu spośród dziesięciu ankietowanych wymieniło nazwisko Czesława Miłosza (pozostałe dwie osoby odpowiedziały na to pytanie wymijająco [Ming 2016]).

Wyniki sondy nie są niespodzianką i odzwierciedlają faktyczną obecność Miłosza w chińskim dyskursie literackim w Państwie Środka. Różnej jakości przekłady dzieł polskiego noblisty, dokonywane czy to bezpośrednio z języka polskiego, czy pośrednio $\mathrm{z}$ angielskiego, autorstwa akademików i poetów, wyrastają jak grzyby po deszczu. W 2018 roku ukazało się czterotomowe wydanie zawierające 335 wierszy Miłosza z lat 1931-2001 w tłumaczeniu trzech wybitnych polonistów: Zhao Ganga, Lin Honglianga oraz Yang Deyou, z których ostatni nie doczekał niestety publikacji wspólnego opus magnum. Mnożą się również eseje poświęcone Miłoszowi, wychodzące spod piór chińskich literatów, a także wiersze z Miłoszem w tytule lub w treści, poczynając od utworów 
nawiązujących do Holocaustu, a kończąc na spacerach w maseczkach po Campo di Fiori i pogoni za zającem w czasie pandemii koronawirusa. Na czym polega fenomen Miłosza w Chinach? Jak się kształtował na przestrzeni dekad? Jakie są źródła jego popularności i jej skutki dla poezji chińskiej i dla samego Miłosza, tj. dla profilu i jakości recepcji jego dorobku? Kto ma, a kto nie ma szans zostać „chińskim Miłoszem”?

Na te i pokrewne im pytania postaram się odpowiedzieć w niniejszym eseju. Nie będzie to systematyczne zestawienie przekładów Miłosza na chiński ani też szczegółowa historia jego obecności w Chinach ${ }^{1}$, ale raczej próba pokazania na dość wyrazistych przykładach, jak poezja polskiego noblisty wpisywała się w główny nurt wydarzeń na tamtejszej scenie poetyckiej, w szczególności w latach 90. xx wieku, czyli w okresie jej najintensywniejszej transformacji, i jak go współtworzyła. Postaram się także ukazać dotychczas niewykorzystany potencjał do dalszego interkulturowego dialogu między literaturą polską a chińską, jaki tkwi w twórczości Miłosza.

\section{Nobel dla Miłosza jako tryumf socjalistycznej literatury}

Poezja Miłosza zawitała do Chin w dość specyficznym okresie kulturalnej historii kraju. Pierwsze, nieliczne, przekłady na język chiński zaczęły pojawiać się na początku lat 8o. ubiegłego stulecia, a więc tuż po uhonorowaniu Miłosza literacką Nagrodą Nobla. Jak nietrudno się domyślić, nie był on dla władz chińskich poetą szczególnie wygodnym. Emigrant, zdrajca komunistycznych ideałów, demaskator totalitaryzmów, niemile widziany we własnej socjalistycznej ojczyźnie, na stałe przebywający w kraju największego kapitalistycznego wroga Chin ludowych. Jeszcze kilka lat wcześniej, za życia Mao Zedonga (1896-1976), z pewnością nie zezwolono by na publikację twórczości Polaka. Przypomnijmy, że w 1976 roku wraz ze śmiercią dyktatora oficjalnie zakończyła

1 Dokładne omówienie historii przekładów Czesława Miłosza na chiński można znaleźć w publikacji Proces tlumaczenia i prezentacji dziet Miłosza w Chinach [Xiong 2016]. 
się trwająca dekadę brutalna rewolucja kulturalna, podczas której kontakt z literaturą zagraniczną był maksymalnie ograniczony, a wszelkie próby jego nawiązania - obwarowane surowymi karami. Od przejęcia władzy przez Deng Xiaopinga w 1978 roku i wprowadzenia polityki reform i otwarcia (gaige kaifang zhengce) cenzura została jednak tymczasowo rozluźniona. Próba nadrobienia straconych lat zaowocowała gorączką kulturalną, przejawiającą się m.in. wzmożoną działalnością translatorską. Na fali tych przemian dotarł do Chińskiej Republiki Ludowej także Miłosz - najpierw za pośrednictwem tajwańskich przekładów autorstwa badacza i poety Du Guoqinga, który w 1982 roku opublikował pierwszy zbiór wierszy Miłosza w języku chińskim, a później także dzięki zaangażowaniu polonistów i poetów z kontynentu.

Nie zmienia to jednak faktu, że nie wszystkie dzieła i nie wszystkie aspekty jego aktywności nadawały się do rozpowszechniania, toteż historycznoliteracką narrację należało od początku odpowiednio sprofilować. Pierwsza odnotowana wzmianka o Miłoszu w oficjalnym dyskursie literackim w ChRL pochodzi z 1982 roku, z czasopisma „Czytanie” („Dushu”). Był to komentarz do angielskiego przekładu Rodzinnej Europy podpisany pseudonimem Jingren. W tym dość zdawkowym tekście autor od razu bardzo wyraziście zdefiniował kierunek myślenia o twórczości Miłosza, odnotowując, że książka opisuje proces dochodzenia Miłosza do zaangażowania w politykę. Przez słowo „polityka” Jingren rozumiał najpewniej krótki okres fascynacji Miłosza komunizmem, jak wynikałoby z dalszej części tekstu, poświęconej walce poety z systemem - przeciwko uciskowi polskiego ludu [Jingren 1982; por. Xiong i Lu 2020: 21].

Narrację tę podjął i ugruntował Lu Yuan (1922-2009), który w 1989 roku opublikował przekład wyboru wierszy wojennych i tużpowojennych The Separate Notebooks (Chaisande bijibu), zredagowanego przez Miłosza na potrzeby zachodniego odbiorcy. We wstępie do chińskiego wydania tłumacz nakreślił obraz autora jako „poety politycznego” (zhengzhi shiren), walczącego piórem w obronie ludu udręczonego rozbiorami kraju i dwiema wojnami. Według Lu dzieło polskiego mistrza ma charakter romantyczno-rewolucyjny, bowiem w czasach dziejowego zamętu nie było miej- 
sca na indywidualizm i metafizykę [Xiong i Lu 2020: 22]. Znaczna przewaga wczesnych wierszy Miłosza pośród tłumaczonych na chiński i dyskutowanych utworów utrzymała się przez kolejne dwie dekady; po dziś dzień zresztą można obserwować taką tendencję, choć w dużo mniejszym stopniu. Xiong Hui i Lu Beibei odnotowują, że pierwszym impulsem do zmiany myślenia o Miłoszu była publikacja w 1995 roku przekładu autobiograficznego tomu Rok myśliwego, a właściwie opis wydawcy inspirowany artykułem z „New York Timesa”. W opisie tym pojawia się następujące stwierdzenie:

Zdziwią się wszyscy, którzy postrzegali Miłosza jako poetę przede wszystkim politycznego. W istocie bowiem Miłosz, którego od tylu lat czytają, przez cały czas oscyluje pomiędzy dwoma skrajnymi biegunami. Służył w życiu zarówno rządowi komunistycznemu, jak i światu zachodniemu. Najważniejsze dla niego były zaś zawsze nacjonalizm i patriotyzm. [cyt. za: Xiong i Lu 2020: 21]

Pomijając kwestię wątpliwej celności reinterpretacji dokonanej w ostatnim zdaniu przez wydawcę Roku myśliwego, był to niewątpliwie pewien krok naprzód. Wróćmy jednak na moment do postaci Lu Yuana i jego ujęcia twórczości Miłosza. Wydaje się bowiem, że podejście to ma głębsze podłoże niźli tylko celowe działanie w służbie państwowej propagandy i domaga się pełniejszego wyjaśnienia.

Lu Yuan w młodości należał do tzw. pierwszej fali chińskiego modernizmu, tj. grupy autorów, którzy w pierwszej połowie XX wieku zrewolucjonizowali poezję chińską, uwalniając ją od sztywnych wzorców klasycznych i wprowadzając do niej język codzienny, tzw. białą mowę (baihua). Pozostawał on pod silnym wpływem ojca współczesnej literatury chińskiej, Lu Xuna (1881-1937), który zresztą jako jeden z pierwszych chińskich twórców zainteresował się literaturą polską, w szczególności Henrykiem Sienkiewiczem i Adamem Mickiewiczem², oraz ówczesnych sław

2 Więcej o roli Lu Xuna w rozpowszechnianiu literatury polskiej w Chinach pisały Li Yinan [2016] oraz autorka niniejszej publikacji [Krenz 2019a]. 
lokalnej sceny poetyckiej, m.in. Ai Qinga (1910-1996), którego Chiny dwukrotnie zglaszały do Nagrody Nobla w drugiej połowie lat 8o. Większość aktywistów literackich w latach 40. z pełnym przekonaniem wstępowała w stopniowo formujące się szeregi partii komunistycznej, dołączając do Mao Zedonga, który notabene znany był wówczas także jako poeta.

Co ciekawe, w tym właśnie okresie Miłosz przełożył na język polski utwory kilku z nich, korzystając z angielskojęzycznej antologii Roberta Payne'a The White Pony z 1947 roku. Byli to: Ai Qing, Wen Yiduo (1899-1946), Bian Zhilin (1910-2000) i Mao Zedong, którego Miłosz przedstawil jako „wyższego wojskowego w armii Czang Hai Szeka” w czasach wojny z Japonią [Miłosz 2005: 191]. Wiedza Miłosza o autorach, odzwierciedlona w szczątkowych notkach biograficznych, w których często otwarcie mówi o braku dostępu do wiarygodnych źródeł, była bardzo niepełna i - jak w przypadku biogramu Mao - nieaktualna. Wątpliwe też, by oni sami wiedzieli o istnieniu tych przekładów. Niemniej, entuzjastyczna pochwała ich dzieł przez Miłosza świadczy o tym, że cechowała ich podobna wrażliwość społeczna i literacka. Podzielali też wspólne inspiracje poezją zachodnią i rosyjską. Dla Miłosza ważny był wówczas przede wszystkim Walt Whitman, którego za swojego patrona uważał m.in. Ai Qing³. Później trajektorie twórczości chińskich modernistów i Miłosza coraz bardziej się rozchodziły. W 1951 roku w słynnym artykule NIE opublikowanym w paryskiej „Kulturze” Miłosz całkowicie zerwał współpracę z komunistycznym rządem. Chińscy poeci zaś na różne sposoby angażowali się w budowę proklamowanej w 1949 roku Chińskiej Republiki Ludowej, upatrując w tym szansy na nowy porządek społeczny, do którego kształtowania pragnęli się aktywnie przyczynić. Wielokrotnie za wierność komunistycznym ideałom płacili zdrowiem

Więcej na temat wspólnych inspiracji oraz rezonansów pomiędzy wczesną twórczością Miłosza i Ai Qinga oraz powodów rozejścia się późniejszych trajektorii ich poezji piszę w przygotowywanej monografii In Search of Singularity: Poetry in Poland and China Since 1989, Brill, Leiden (planowana data publikacji: 2022). O inspiracjach Whitmanowskich u Miłosza pisali Marta Skwara [2004] i Arent van Nieukerken [2012]; o tychże inspiracjach u Ai Qinga pisali Huang Guiyou [1997, 1998] i Chen Xuan [2013]. 
lub wolnością, wystawiani na próbę przez własny rząd w kolejnych kampaniach i czystkach prowadzonych przez dyktatora. Kiedy jednak w 1976 roku represje, które dotknęly niemal wszystkich intelektualistów, niezależnie od poglądów politycznych, ustały, autorzy ci ponownie zaczęli się liczyć na scenie literackiej jako tzw. Poeci Powracający (guilai shiren) ${ }^{4}$. Wielu odzyskało też miejsce w strukturach politycznych i oficjalnych instytucjach kulturalnych.

W międzyczasie jednak uformowało się także młode pokolenie poetów, których początki twórczości przypadały na czasy rewolucji kulturalnej. Dla nich inspiracją były przeważnie nielegalnie zdobywane książki z Zachodu. Najbardziej znaną nieformalną grupę spośród nich stanowili tzw. Poeci Mgliści (menglong shiren), wśród których znaleźli się m.in. Bei Dao (ur. 1949), Mang Ke (ur. 1950), Duoduo (ur. 1951), Shu Ting (ur. 1952), Yang Lian (ur. 1955). O ich twórczości często mówi się jako o drugiej fali modernizmu w Chinach. Poeci Mgliści oraz debiutująca nieco później tzw. Trzecia Generacja (di san dai) określani są dziś zwykle mianem awangardy, choć termin ten ma nieco inny sens niż w kontekście kultury euroamerykańskiej. Zwykle jest definiowany po prostu w opozycji do „poezji ortodoksyjnej” (zhengtong shige), a więc działającej przy wsparciu struktur państwowych, do której twórców zalicza się większość Poetów Powracających.

Pomiędzy Powracającymi a Mglistymi wywiązał się konflikt pokoleniowy, estetyczny i ideologiczny, którego głównymi bohaterami stali się Ai Qing i Bei Dao. Powracającym bliski był socrealizm oraz rewolucyjny realizm romantyczny i myślenie o poezji w kategoriach odpowiedzialności politycznej za naród. Uważali też, że po latach cierpień należy im się przewodnia rola w państwie. Mgliści zaś domagali się dowartościowania jednostki i postulowali oddzielenie literatury od polityki rządu centralnego. To ich poezja towarzyszyła w 1989 roku upominającym się o demokrację studentom na placu Tian'anmen. Sam Lu Yuan początkowo, we wczesnych latach 8o., stawał po stronie Mglistych, czując się w obowiązku 
bronić młodszych kolegów po piórze przed atakami swoich rówieśników oraz naciskami ze strony polityków. Wkrótce jednak i on dołączył do grona przeciwników ich twórczości [Jiang i Li 2015].

Przy takim układzie sił na poetyckiej scenie i polemikach, w których stawką były rola i miejsce poezji w nowoczesnym społeczeństwie, Miłosz w tłumaczeniu Lu Yuana musiał pozostać poetą możliwie wyrazistym, nieambiwalentnym, „poetą ludu”, jak Whitman, by przypadkiem nie osunąć się w „mglistą” poetykę nadmiernego indywidualizmu. I tak oto w oficjalnym dyskursie Nobel Miłosza stał się tryumfem socjalistycznej kultury. Nie zmienia to jednak faktu, że przekłady Lu, nawet jeśli niewolne od merytorycznych usterek, były literacko dobre i przyczyniły się do ogromnego zainteresowania Miłoszem nie tylko w gronie twórców ortodoksyjnych, ale może przede wszystkim pośród poetów Trzeciej Generacji, szukających alternatywy dla wzorców stworzonych przez Bei Dao i pozostałych Mglistych.

\section{Szukamy nauczyciela i mistrza}

Wieloletni konflikt na linii Powracający - Mgliści, czy szerzej: ortodoksja - awangarda obfitował w agresywne starcia. Wbrew utartemu scenariuszowi literackiej sztafety pokoleń prowodyrami nie byli jednak młodsi, snujący plany symbolicznego ojcobójstwa, lecz weterani pod wodzą Ai Qinga, który po 20 latach tułaczki po kraju, na przełomie lat 70. i 8o. hołubiony przez władze stał się ikoną i głównym produktem eksportowym socjalistycznej kultury z chińską charakterystyką. Jeszcze za czasów rewolucji kulturalnej Ai Qing przyjaźnił się z Bei Dao, a jego syn, obecnie znany dysydent, artysta Ai Weiwei ilustrował kultowe pismo Mglistych - „Dzisiaj” („Jintian”). Z niejasnych powodów jednak, odzyskawszy dawną pozycję, zaufanie i szacunek ze strony władz, Ai Qing we wczesnych latach 8o. zaczął występować z coraz ostrzejszą krytyką poezji Mglistych, początkowo na gruncie czysto estetycznym, a później także ideologicznym. W ten sposób przyczyniał się do pogłębiania się represji wobec nich w czasie tzw. kampanii przeciw duchowemu zepsuciu ${ }^{5}$. 
Wspominam o tej okoliczności, by zwrócić uwagę na nieciągłość pokoleniową w rozwoju poezji chińskiej, w szczególności brak tak ważnej dla polskiej poezji figury Starych Mistrzów, stanowiących punkt odniesienia dla twórczości młodszych autorów. To fakt kluczowy dla późniejszej wzmożonej recepcji Miłosza w Chinach. O ile w Polsce poeci pokolenia „Brulionu” buntowali się przeciw dominacji Wielkiej Czwórki: Miłosza, Szymborskiej, Różewicza i Herberta, czując się przytłoczeni nie tylko ich artystycznym dorobkiem, lecz także autorytetem moralnym oraz społecznym poważaniem, o tyle w Chinach potencjalni kandydaci na Starych Mistrzów, rówieśnicy polskiej Wielkiej Czwórki, w większości zdążyli skompromitować się w oczach młodego pokolenia swoją uległością wobec systemu, brakiem ducha oporu oraz samodzielności twórczej i intelektualnej. Dodatkowo zniechęcili do siebie młodych twórców wrogim nastawieniem i brakiem solidarności w obliczu konfliktu z władzami. Mgliści, niesieni reformatorskim zapałem i młodzieńczą pewnością siebie, nie przejawiali nadmiernego zainteresowania kwestią konstruowania poetyckich lineaży, ale dla Trzeciej Generacji stało się to jednym z kluczowych aspektów budowania własnej tożsamości poetyckiej.

Do Trzeciej Generacji zalicza się poetów rocznikowo niewiele młodszych od Mglistych, urodzonych w większości między rokiem 1955 a 1964, którzy debiutowali w cieniu Mglistych pod koniec lat 70. i w pierwszej połowie lat 8o. Była to grupa od początku bardzo zróżnicowana. Jej członków łączyło wspólne pragnienie przerwania dominacji Mglistych na awangardowej scenie poetyckiej oraz zwrócenie poezji w kierunku doświadczeń życia codziennego, ukonkretnienie jej i nadanie bardziej osobistego rysu, odmiennego niż romantyczno-heroiczny indywidualizm Bei Dao. W przeciwieństwie do pierwszego pokolenia modernistów już wówczas ok. trzydziestoletni autor postrzegany był jako ktoś w rodzaju Bloomowskiego poety silnego, z którym trzeba było otwarcie się zmierzyć. W połowie lat 8o. Trzecia Generacja wypowiedziała mu symboliczną wojnę, posługując się hasłami, takimi jak „Pass Bei Dao”. Trudno było jednak młodszym poetom zdobyć w społeczeństwie taką popularność, jaką osiągnęli Mgliści, których nazwiska były na ustach całego narodu, cieszący się statusem równym statu- 
sowi gwiazd popkultury. Potyczki międzypokoleniowe toczyłyby się pewnie dalej, gdyby nie fakt, że po tragicznym 4 czerwca 1989 roku większość Mglistych, w tym ich niepisany lider, zmuszona została do emigracji z kraju. Na lokalnej scenie poetyckiej pozostawili osamotnionych autorów Trzeciej Generacji, wśród których impuls ojcobójczy dość szybko ustąpił miejsca bratobójczemu.

Mimo wspólnego celu, jakim było wyjście z cienia Mglistych Poetów, mniej więcej od połowy lat 8o. między autorami Trzeciej Generacji zaczął się rysować coraz wyraźniejszy podział na dwie frakcje o stopniowo radykalizujących się poglądach. Po jednej stronie znaleźli się poeci nazwani później Intelektualistami (zhishifenzi shiren), głównie wywodzący się z pekińskiego środowiska akademickiego, postulujący bardziej intensywne czerpanie z wzorców zachodnich, elitaryzację i umetafizycznienie chińskiej poezji. Wśród nich byli m.in. Wang Jiaxin (ur. 1957), Ouyang Jianghe (ur. 1956), Xi Chuan (ur. 1963), Sun Wenbo (ur. 1956), Song Lin (ur. 1959), Zhang Shuguang (ur. 1956), Xiao Kaiyu (ur. 1960) czy Zang Di (ur. 1964). Po drugiej stronie stanęli tzw. poeci minjian (minjian shiren), co w przybliżeniu przetłumaczyć można jako poeci (z/dla) ludu, określani dalej przeze mnie, z braku celniejszego sformułowania w polszczyźnie, jako Ludowcy, przy czym lud interpretować tu należy raczej po Whitmanowsku niż w duchu socjalistycznym. Ludowcy z kolei postulowali odmetafizycznienie i odmetaforyzowanie poezji, jej większą łączność z tradycją lokalną i powrót do przedkulturowego stanu języka jako medium czysto metonimicznego przekazu. Przedstawicielami tej grupy byli przede wszystkim Yu Jian, Han Dong czy Lü De’an (ur. 1960).

Nie miejsce tu na rekonstrukcję całej polemiki między Intelektualistami a Ludowcami, której skutki można odczuć w Chinach do dziś ${ }^{6}$. W kontekście niniejszego tematu istotne jest przede wszystkim bardzo intensywne poszukiwanie przez Intelektualistów wzorców, swego rodzaju zastępczych ojców, w poezji zagranicznej, w tym zwłaszcza w krajach o podobnym doświadczeniu historycznym, wobec braku autorytetów na rodzimej scenie literackiej, oraz

6 Bardziej szczegółowo piszę na ten temat w innych publikacjach [zob. Krenz 2017, 2018]. 
konsekwentne kwestionowanie pozycji tychże ojców zastępczych przez Ludowców i demontowanie literackich rodowodów pieczołowicie konstruowanych przez adwersarzy. Czarę goryczy wzbierającą między stronnictwami przelał wyjątkowo tendencyjny poetycki tom antologii Portret minionych lat. Seria poświęcona literaturze lat 9o. (Suiyue de yizhao - jiushi niandai wenxue xishu), zredagowany w 1998 roku przez krytyka Cheng Guangweia, sympatyzującego z Intelektualistami. Tom ów zawierał jedynie utwory tej frakcji i poprzedzony był kontrowersyjnym wstępem, w którym Cheng ubolewał nad niesamowystarczalnością chińskiej poezji i słabością jej własnej tradycji oraz podkreślał kluczowy charakter zachodnich źródeł współczesnej twórczości poetyckiej w Chinach77. Jako jeden z filarów zachodniej poezji w jego tekście wymieniony został Miłosz, wcześniej „przyporządkowany” jako patron do dwóch rodzimych autorów: Zhang Shuguanga (jednego z najaktywniejszych tłumaczy Miłosza) i Wang Jiaxina, choć bez poparcia owej hipotezy przykładami konkretnych nawiązań w wierszach.

Mówi się czasem, że ponieważ chińska poezja klasyczna nie pozostawiła wystarczającej przestrzeni estetycznej do rozwoju poezji współczesnej, to poezja ta musiała zrodzić się i rozwijać w łonie tradycji zachodniej. $\mathrm{Z}$ takiego postawienia sprawy wynika założenie: o poezji lat 9o. można dyskutować jedynie w kategoriach zachodnich upodobań poetyckich. Nie mam najmniejszych wątpliwości, że za współczesną poezją chińską stoi szczerość i odpowiedzialność wynikająca z wielkości charakteru autorów. Zastanawiam się jedynie, czy trudne okoliczności, w których przyszło im tworzyć, sprzyjają rozsądnemu rozwojowi tej poezji. Z jednej strony usiłujemy, posługując się Eliotem, Audenem, Yeatsem, Miłoszem, Mandelsztamem i kierując się skrajnie zmiennymi gustami zagranicznych sinologów, budować coś, co w istocie jest fikcją poetyckiej tradycji. Z drugiej strony, w głębi serca doskonale rozumiejąc kulturę i język Hanów, sami

7 Dokładne omówienie polemiki, w tym tekstu Chenga oraz najważniejszych odpowiedzi na jego tezy, znajduje się w publikacji Chinese Poetry in Times of Mind, Mayhem and Money [van Crevel 2008 (Chapter Twelve)]. 
nie wierzymy w tę budowaną na piasku „tradycję”. Z jednej strony, staramy się zachować czujność wobec tak zwanej „międzynarodowej sceny poetyckiej”. $Z$ drugiej strony, ogromnie pragniemy uznania w jej oczach, aby zyskać jakiś standard definiujący wielkiego poetę. $Z$ jednej strony, chcielibyśmy być Don Kichotami, którzy nacierają bez lęku i zastanowienia na obozy wroga. Z drugiej strony, choćbyśmy posunęli się i sto kroków naprzód, będziemy i tak co najwyżej wiecznie się wahającymi Hamletami. Nasze wychowanie i osobowość nie pozwolą nam wyjść poza bezowocne artystyczne ćwiczenie. [Cheng 1998] ${ }^{8}$

W odpowiedzi na tekst Chenga ze strony Ludowców posypały się inwektywy i otwarte oskarżenia rzucane z retoryczną nonszalancją. Intelektualistów nazwano m.in. zdrajcami, kompradorami współpracującymi z kolonialną potęgą, nędznymi imitatorami, pseudowygnańcami uzurpującymi sobie status i duchowe przywileje cierpiących za ojczyznę, poetami piszącymi „pod sinologów”, „pod tłumaczenie” albo też stylem „tłumaczeniowym”, zapożyczonym z obcych literatur, nienaturalnym dla języka chińskiego. Intelektualiści oczywiście odgryzali się od czasu do czasu, ale ponieważ agresja i uszczypliwość leżały jednak poza wyznawanym przez nich etosem poety, zostali niemal zakrzyczani przez oponentów. Jednak spoglądając na sytuację nieco szerzej, nie można zignorować faktu, że to właśnie oni mieli przywilej dostępu do ważnych instytucji wydawniczych oraz wpływowych mediów w stolicy, więc tak naprawdę ostatnie słowo należało do nich i to ich wizja poezji miała większe szanse dotrzeć do szerszego grona czytelników.

Tak czy inaczej, marka Miłosz, a właściwie Miwoshi, w przybliżonym przekładzie fonetycznym na chiński, w latach 9o. trafiła w ręce Intelektualistów, choć po drugiej stronie frontu spotykała się przez lata raczej z umiarkowanym zainteresowaniem. Lian Hansheng, były student Wang Jiaxina, sam również będący rozpoznawalnym poetą, w imponujących rozmiarów pracy doktorskiej napisanej pod kierunkiem Wanga Między „świadectwem” a „radoś-

8 Wszystkie tłumaczenia w tekście wykonane zostały przez autorkę bezpośrednio z języka oryginału - J.K. 
cia". Miłosz, Brodski i Heaney a wspótczesna poezja chińska (Zai 'jianzheng' yu 'yuyue' zhijian - Miwoshi, Buluociji he Xini yu Zhongguo dangdai shige) przekonuje, że po „intelektualnej” stronie poetyckiej sceny nie było autora, który nie przeszedłby przez „chrzest Miłosza” [Lian 2016: 138]. W jego twórczości szczególnie upodobali sobie oni figurę poety jako świadka. O ile, jak dowodzi Lian, tuż po wydarzeniach na Tian’anmen w świadomości poetów, którzy pozostali w kraju, dominowała postawa i mentalność „ocalonych” (xingcunzhe), którzy nie do końca wiedzieli, co zrobić z wolnością, bowiem tak wielu ich rówieśników zostało jej pozbawionych, o tyle u progu lat 90., dzięki pogłębionej lekturze Miłosza, zwrócili się ku postawie świadectwa, wymagającego przyjęcia współodpowiedzialności za losy narodu [Lian 2016: 138].

Monopolizacja Miłosza przez Intelektualistów miała dwojakie skutki. Z jednej strony za niewątpliwą zasługę należy im poczytać odbicie Miłosza z rąk poetów i krytyków ortodoksyjnych i dekomunizację jego recepcji w Chinach. Z drugiej strony forsowany przez nich paradygmat interpretacji jego twórczości również nie był pozbawiony wad, o czym postaram się przekonać Czytelników, ukazując przykłady konkretnych dialogów z Miłoszem, by na koniec, w części poświęconej Wierszom z Polski (Bolan shipian) Lei Pingyanga (ur. 1966), przeanalizować spektakularną dekonstrukcję wykreowanego przez Intelektualistów obrazu Noblisty, a tym samym i pewnego systemu myślenia o poezji, ukształtowanego przez polemikę dwóch obozów, którego obraz ten był produktem. Jednocześnie Lei, sytuujący się poza dawnymi podziałami, wydaje się sam kreować poetykę najbliższą Miłoszowi - takiemu, jakiego znamy, a właściwie takiemu, jakiego nie znamy, z polskiego i euroamerykańskiego dyskursu, a więc pełnemu wewnętrznych sprzeczności, niejasności, kontrowersyjnemu i pojemnemu jak świat, by przywołać słynną formułę Jana Błońskiego.

\section{Od obozów koncentracyjnych do koronawirusa.}

\section{Miłosz Wang Jiaxina}

Wang Jiaxin [2007] tak rozpoczynał swój esej W świadectwie poezji (Zai shige de mudu xia), napisany w 2007 roku: 
Pod koniec lat 8o., kiedy powoli zaczęła przygasać „gorączka modernizmu" w kręgach poetyckich i intelektualnych, przed oczyma chińskich poetów ukazał się prawdziwy wschodnioeuropejski poeta. Był to właśnie Czesław Miłosz.

Myślą przewodnią tego tekstu jest Miłoszowe stwierdzenie zawarte w cyklu wykładów amerykańskich Świadectwo poezji, pominięte jednak w polskim wydaniu książki: „I have titled this book The Witness of Poetry not because we witness it, but because it witnesses us” („Zatytułowałem tę książkę Świadectwo poezji nie dlatego, że to my świadczymy o poezji, lecz dlatego, że to ona świadczy o nas") [Miłosz 1983: 4]. Esej ten w połowie poświęcony jest Miłoszowi, a w połowie Adamowi Zagajewskiemu, który jest Wangowi szczególnie bliski. W rozszerzonej - m.in. o komentarz do twórczości Wisławy Szymborskiej - formie, jako „Świadectwo poezji” i „Mistyka dla poczatkujacych”. Od Mitosza do Zagajewskiego ('Shi de jianzheng' yu 'Shenmixue rumen' - cong Miwoshi dao Zajiayefusiji) tekst został włączony do dwóch tomów krytycznoliterackich Wanga: Mistrz, który nauczyt moja duszę śpiewać (Jiao wo linghun gechang de dashi) oraz Przekład jako rozpoznanie (Fanyi de bianren) z 2017 roku. W obu tych tomach, raz z perspektywy ucznia i kontynuatora, raz z perspektywy tłumacza, którego zadanie rozumie Wang w duchu Waltera Benjamina, autor mówi o zagranicznych poetach odgrywających znaczącą rolę w jego własnej twórczości i dziełach tłumaczonych przezeń na chiński. Są wśród nich m.in. Thomas Stearns Eliot, Wystan Hugh Auden, Seamus Heaney, Marina Cwietajewa, Osip Mandelsztam, Anna Achmatowa, Borys Pasternak, Josif Brodski, Reiner Maria Rilke, Paul Celan, Tomas Tranströmer, René Char, Federico García Lorca.

Zarówno tytuły - utrzymane w charakterystycznej dla Wanga poetyce - jak i dobór nauczycieli oraz mistrzów wskazują na bardzo specyficzny obszar zainteresowań i poszukiwań autora, obejmujący w dużej mierze (choć nie tylko) poetów tzw. wysokiej dykcji oraz o trudnym doświadczeniu osobistego uwikłania w historię. Wang silnie identyfikuje się z nimi na dwóch płaszczyznach. Po pierwsze, przemawia jako Chińczyk dostrzegający analogie między współczesnymi dziejami swojego kraju a dziejami zwłaszcza państw 
wschodnio- i środkowoeuropejskich w Xx stuleciu i w dużej mierze dokonujący przepisania własnych traum, o których nie wolno mu mówić otwarcie w totalitarnym państwie, na narrację skupioną wokół Holocaustu. To zresztą było jednym z istotnych zarzutów Ludowców wobec Intelektualistów. Xu Jiang (ur. 1967) np. wypominał pekińskim autorom, że zamiast o masakrze w Nankinie i o rewolucji kulturalnej mówią o Auschwitz [van Crevel 2008: 415]. Wśród młodszych poetów, których ukształtowała poetyka Intelektualistów, identyfikacja z problematyką poruszaną przez Miłosza pogłębiła się. Przykładowo Sang Ke (ur. 1967), recenzując Świadectwo poezji, pół żartem, pół serio spostrzegł ze zdziwieniem, „że Miłosz jest poetą chińskim, jak się patrzy” [cyt. za: Lian 2016: 243]. Pośrednio taka praktyka mapowania chińskich traum na polskie terytorium przyczyniła się do wytworzenia bardzo specyficznego obrazu Polski w chińskim dyskursie literackim, o czym pisałam we wcześniejszym artykule [Krenz 2019b]. Wrócę jeszcze na chwilę do tego zagadnienia przy omawianiu Wierszy z Polski Lei Pingyanga, który z kolei winą za ukształtowanie się takiego, a nie innego obrazu Polski po części obarcza właśnie Miłosza. Po drugie zaś Wang przekonany jest o istnieniu wspólnoty osobistych losów pomiędzy nim a wielkimi mistrzami, których wymienia, szczególnie w kontekście poetyki wygnania, rozumianego, zarówno w wymiarze fizycznym, jak i przede wszystkim duchowym, jako poczucie nieprzystawalności i niemożność znalezienia sobie miejsca w ojczyźnie. Choć on sam nigdy nie stał na pierwszej linii frontu walki o demokrację, i jego po masakrze na Tian’anmen nie ominęly represje. Stracił m.in. stanowisko redaktora „Miesięcznika Poetyckiego” („Shikan”), co skłoniło go do podjęcia decyzji o udaniu się na tymczasową emigrację do Londynu, gdzie spędził półtora roku (1992-1993). Później wielokrotnie podróżował do miejsc związanych z wielkimi poetami, z którymi łączy go, jego zdaniem, szczególna komunia duchowa. Traktował te spotkania jako klucz do definicji własnej tożsamości. W rozmowie z Johnem Crespim wyznaje:

Za granicą odwiedziłem dawne domy niektórych z moich ulubionych poetów, artystów i filozofów. Ale to nie to samo, co zwykła wycieczka, i nie to samo, co ludzie często określają 
mianem pielgrzymki. To jest związane z głębszym samorozpoznaniem, to pewien rodzaj dialogu z sobą.

$[\ldots]$

Teraz, kiedy wywołuję imiona tych wielkich poetów, bynajmniej nie robię tego, by się nobilitować. Chodzi mi o to, że choć nasze życia dzieli język i kultura, wszyscy zmierzamy ku tej ,jednej duszy”. [Wang 2011: 79-80]

W jeszcze innym miejscu zaś, wymieniwszy Miłosza w jednym szeregu z Yeatsem, Rilkem, Pasternakiem, Brodskim, Achmatową, Celanem, Heaneyem, Qu Yuanem, Du Fu i Dantem, nazywa ich swoimi „bóstwami opiekuńczymi” (shouhushen), i dodaje:

[... ] wybrałem sobie ich z całej historii, bo oni dla mnie są całą historią. Całym jej cierpieniem i całą chwałą. „Przybyli z przeszłości, ale stają przed naszymi oczami”, ich istnienie ma szczególne znaczenie dla mojego życia i pisarstwa. [cyt. za: Lian 2016: 179]

Esej W świadectwie poezji [Wang 2007], który stanowi najpełniejszą w dorobku Wanga wypowiedź poświęconą Miłoszowi, autor rozpoczyna od krótkiej rekonstrukcji biografii noblisty, by w kolejnych akapitach wspomnieć, jakie wrażenie wywarły u progu lat 90. na nim samym i innych poetach chińskich słowa z Miłoszowego Zadania: „W trwodze i drżeniu myślę, że spełniłbym swoje życie, / Tylko gdybym się zdobył na publiczną spowiedź, / Wyjawiając oszustwo, własne i mojej epoki” [Miłosz 2011: 605], w połączeniu z lekturą dostępnych wówczas w języku chińskim fragmentów Świadectwa poezji. To właśnie pod tym „świadczącym spojrzeniem” $(m u d u)$ - stwierdza Wang - „w latach 9o. poezja chińska odzyskała głos”. Przywołuje Campo di Fiori jako wiersz, w którym wyrażony jest imperatyw przeciwdziałania „zapomnieniu, co rośnie / Nim jeszcze płomień przygasnął” [Miłosz 2011: 193], oraz Elegię dla N.N., w której Miłosz wyrzuca sobie i swoim współczesnym, że „nie kochaliśmy jak należy / Biednego popiołu w Sachsenhausen / Miłością absolutną nad miarę człowieka” [Miłosz 2011: 616]. Przenosząc refleksje Miłosza na chińską rzeczywistość i wzmacniając je 
Havlowską formułą konieczności „życia w prawdzie”, Wang mówi dalej o wyzwaniach stających przed współczesnymi poetami chińskimi, o tym, że „życie w prawdzie” oznacza dla nich „życie pod presją”, „życie w konflikcie” i „życie w problemach”, by wreszcie dopatrzeć się światełka nadziei w wierszu Pokusa, na który powołuje się także w kilku innych komentarzach jako na jeden z najważniejszych dla siebie tekstów. Co ciekawe jednak, najważniejsze dlań słowo z owego najważniejszego tekstu również (podobnie jak zdanie ze Świadectwa poezji) nie występuje w oryginale wiersza. Wang powołuje się na słowa, które po polsku brzmią: „bo nie ja, to inny / Chodziłby tutaj i chciał swój wiek zrozumieć” [Miłosz 2011: 696]. W angielskim przekładzie zamiast „chcieć” występuje słowo „próbować” (try), tak samo jak w chińskim tłumaczeniu, w którym pojawia się shitu, odpowiednik angielskiego try. Miłoszowe dość pasywne „chcenie” zamienia się więc w konkretny moralny nakaz aktywnego próbowania i dowód odwagi poety, która niejako go usprawiedliwia, choćby nawet próby owe nie miały przynieść powodzenia:

W obliczu świata, który zawsze przekracza nasze możliwości pojmowania, w owym „próbowaniu” właśnie kryje się cała trudność sztuki, ale i cała odwaga pisarza. A oprócz odwagi, cała jego wierność i mądrość. [Wang 2007]

Podsumowując refleksję nad wierszem, Wang [2007] ponownie podkreśla rolę Miłosza w definiowaniu tożsamości poezji lat 90.:

W poezji Miłosza przed oczyma chińskich poetów w latach 90. ukazała się ważność i złożoność historii. Oto pojawił się pewny punkt odniesienia w podejmowanych ustawicznie w latach 80 . próbach odpowiedzi na pytanie: „cóż po poecie?”. To pozwoliło im lepiej zrozumieć ich własną epokę.

W samej poezji Wanga z wczesnych lat 9o. również odzwierciedla się podobny stosunek do Miłosza. W dwóch „fragmentach poetyckich" (shi pianduan) z 1991 roku, a więc z okresu, kiedy autor prawdopodobnie przygotowywał się na wyjazd do Londynu, poja- 
wiają się nawiązania do polskiego noblisty - z jednej strony jako współbrata w cierpieniu, który musiał sprostać podobnym problemom, a z drugiej jako mistrza stanowiącego wyznacznik pewnych estetyczno-etycznych standardów. W dwuzdaniowym utworze Wygnanie: dla Miłosza (Liuwang: zhi Miwoshi) czytamy: „Skoro uczyniłeś ten krok, nie wolno ci odwracać głowy. Bogini pamięci nie pozwoli ci zaznać spokoju" [cyt. za: Lian 2016: 260]. Kontekst twórczości Wanga pozwala przypuszczać, że są to raczej słowa kierowane do samego siebie, nie do Miłosza. Autor przewiduje dla siebie niełatwą przyszłość i, wpatrzony w przykład polskiego mistrza, napomina sam siebie, by nie ulec pokusie żony Lota i konsekwentnie iść naprzód. Aby jednak wygnanie nie przerodziło się $\mathrm{w}$ stan rozproszenia i pustego uniesienia, przykazuje sobie, jak Miłosz, uchwycić się czegoś rzeczywistego - jakiejś rzeczy czy wartości. O tym mówi Pokusa (Youhuo) ze wspomnianego cyklu fragmentów, nawiązująca do Miłoszowego wiersza o tym samym tytule. W języku chińskim intertekstualność jest w tym utworze jeszcze bardziej widoczna, pojawia się bowiem sformułowanie „w tych czasach” (zai zhe ge shidai) jako aluzja do "swoich czasów” występujących w przekładzie Pokusy Miłosza jako chińska wersja polskiego sformułowania „swój wiek”. Oto jak Wang rozprawia się z pokusą fruwania na skrzydłach czystej poezji, którą podobnie jak Miłosz traktuje z niechęcią graniczącą z pogardą: „W tych czasach, jeśli nie uda mi się do śmierci wytrwać przy jednej rzeczy, to zacznę dryfować. Dryfować po ulicach albo między wierszami, albo w wierszu" [cyt. za: Lian 2016: 261].

Z kolei w Stowach (Ciyu), zbiorze poetyckich notatek osnutych często wokół anegdot i cytatów ze swoich literackich autorytetów, wspomina, jak wstrząsnęła nim rzucona przez Miłosza niby mimochodem myśl, że tego, co wydarzyło się raz, nie sposób zatrzymać w słowie [Wang 2001b: 278-279].

Trudno powiedzieć, co dokładnie tak poruszyło Wanga: czy świadomość beznadziejności stawianego przez poetami zadania niesienia świadectwa, czy też nagłe poczucie bezcelowości tego, co Miłosz zwykł nazywać „namiętną pogonią za rzeczywistością”, mając na myśli nie tyle rzeczywistość zmysłową, ile metafizyczną, której epifanii doświadczyć pragnął poprzez poezję? Biorąc pod 
uwagę ówczesne rozłożenie akcentów w twórczości Wanga oraz dobór cytatów z innych autorów w Stowach, można przypuszczać, że najpewniej zastanawiał się wówczas nad sensem pisania jako uczestnictwa w historii i kształtowania zbiorowej pamięci.

Pisząc w 2007 roku W świadectwie poezji, Wang oczywiście zdaje sobie sprawę, że Miłosz to nie tylko poezja historycznego obowiązku, ale także namysł nad „problemami jeszcze głębiej ukrytymi w ludzkim bycie” [Wang 2007]. Przywołuje więc zdawkowo Studium samotności i Dar, który cieszy się dziś bodaj największą popularnością spośród wierszy Miłosza i doczekał się już kilkunastu przekładów na chiński, o których nieco więcej powiem pod koniec niniejszego artykułu. Ów metafizyczny Miłosz nigdzie jednak nie przenika do jego własnej twórczości. Także w późniejszym o 10 lat eseju „Świadectwo poezji” a "Metafizyka dla początkujacych", stanowiącym rozwinięcie dzieła $W$ świadectwie poezji, zachowana zostaje podobna proporcja. Wang obszernie omawia w tym tekście m.in. Przedmowę skupioną wokół pytania: „czym jest poezja, która nie ocala” w przekładzie Zhang Shuguanga. Zarazem dokonuje rekonstrukcji wojennego tła powstania wiersza oraz kryjących się za nim moralnych dylematów. Kiedy zaś przechodzi do Daru, uruchamia bardzo znamienny lokalny kontekst, mianowicie poezję Haizi (1964-1989), którego samobójczą śmierć w 1989 roku, u progu „pekińskiej wiosny”, Intelektualiści uczynili jednym z mitów założycielskich swojej poetyki. Haizi, „męczennik poezji”, autor wielu romantyczno-heroicznych utworów kreujących postać poety jako mesjasza narodu, syna Słońca, spalającego się w ogniu pasji jeźdźca na mitycznym rumaku, ma w swoim dorobku bardzo znany, wyróżniający się w jego dziele stoicką pogodą liryk Twarza ku morzu otwieraja się kwiaty w wiosennym cieple (Mianchao dahai, chunnuan hua kai). Wang twierdzi, że mimo różnic, które dostrzega pomiędzy pełnym ozdobników stylem „dużego dziecka” (dahaiziqi) Haizi a surowym pisarstwem doświadczonego poety, za obydwoma wierszami „stoi cała historia doświadczona przez autorów” [Wang 2017: 206], a bijący z tekstów spokój jest dowodem zdolności poetów do przekroczenia jednostkowej perspektywy i cierpienia oraz spojrzenia na własne życie z perspektywy porządku kosmicznego. Taka specyficzna fuzja figury Starego 
Mistrza tudzież zastępczego ojca z figurą młodego męczennika jest znamienna dla Intelektualistów. Obecna była zresztą także w twórczości samego Haizi, który otaczał miłością „książąt poezji” (a więc głównie poetów romantycznych i poetów przeklętych), a czcią „królów poezji”, którzy stanowili niepodważalne autorytety i którym udało się dotknąć istoty świata (Goethe, Dante, Szekspir) [Haizi 1986]. Obie te figury składają się na paradygmat, który Ludowcy nazywali złośliwie za Milanem Kunderą „życiem gdzie indziej" (shenghuo zai biechu) i krytykowali jako koronny dowód niezdolności adwersarzy do samodzielnego i bezpośredniego skonfrontowania się z rzeczywistością.

Ukształtowana przez inspiracje Miłoszowskie poetyka świadectwa pozostała cechą twórczości Wanga po dziś dzień, choć bezpośrednich aluzji do noblisty, poza wspomnianymi miniaturami, trudno w niej szukać aż do... 2020 roku. Jak niegdyś w notatkach $\mathrm{z}$ wygnania, tak obecnie $\mathrm{w}$ Wangowych zapiskach z czasów zarazy Miłosz powraca $\mathrm{w}$ dwóch utworach $\mathrm{z}$ sześciu. Pierwszy z nich to krótki wiersz Biegnij, zającu (Pao ba, tuzi), napisany 24 lutego, rozpoczynający się od przywołania sceny ze Spotkania Miłosza:

Nie był to zając którego napotkał przed świtem Miłosz na zmarzniętej ziemi

Nie był to też zając którego widziałem w dzieciństwie na polu pszenicy otoczonego przez pastwiący się nad nim tłum

Był to przerażony zając

który po trzydziestu dniach izolacji miasta przemknął pośród głębokiej nocnej ciszy

Był to zając nagle pochwycony przez promień ostrego [światła, jakby

wybiegł prosto z naszych snów

Zając uskoczył sprzed maski auta w blasku reflektorów jak gdyby się wyrwał spod noża masarza 
To była dusza, zlękniona dusza

która zanim znów zostanie pochwycona przez śmierć wykonała ostatni skok

24.02 .2020

[Wang 2020]

Choć Wang na początku zaznacza, że „Nie był to zając którego napotkał przed świtem Miłosz", to jego myśli biegną w podobną stronę co myśl Miłosza w Spotkaniu: ku refleksji o przemijaniu i odwiecznemu pytaniu: ubi sunt? O ile jednak Miłosz występuje w Spotkaniu raczej w roli filozofa-mistyka, zastanawiając się: „Miłości moja, gdzież są, dokąd idą / Błysk ręki, linia biegu, szelest grud - / Nie z żalu pytam, ale z zamyślenia” [Miłosz 2011: 151], o tyle Wang trwa jako świadek, starając się mimo wszystko uchwycić to, co zdarzyło się raz i czego nie da się zatrzymać w słowie: ostatni skok duszy przez wpadnięciem w uścisk śmierci.

Drugi wiersz to powstały trzy tygodnie później kilkuczęściowy poemat Wtochy (Yidali), w którym Wang uwiecznia zmagania Włochów z epidemią. Po obszernej opowieści o wielkiej starożytnej kulturze włoskiej oraz wspomnieniach z własnych wypraw, w części piątej autor odmalowuje pandemiczny krajobraz:

Ale to końcówka lutego 2020 roku, w piekle Dantego zrywa się wichura, wirus pędzi szybciej od czapli...

Alarmy. Plany. Filozofowie, lekarze

i teolodzy jeszcze się kłócą na łamach gazet.

Tak, za późno przybyłem do Włoch (ale wcześniej też nic by [nie dało)

nagle na opustoszałych wydezynfekowanych ulicach

nie możemy nawet jak Nietzsche w Turynie

płakać przytuleni do końskiej szyi.

[Wang 2020] 
W części ósmej zaś powraca motyw z Campo di Fiori, o którym Wang napisał krótki esej po swojej wizycie w Rzymie w 2001 roku. Mówił wówczas o placu jako o „nieustannie odnawiającej się ranie sumienia ludzkości” i o cierpieniu Giordana Bruna, które dopiero po kilkuset latach zostało przez „przybyłego z Polski poetę” wypowiedziane „językiem wolności, którego [ludzkości - J.K.] bynajmniej do końca nie odcięto” [Wang 2001a]. Myśl znów kieruje Wanga na Campo di Fiori 19 lat później:

A więc mów dalej. Mimo że przybyliśmy za późno.

Przegapiliśmy wybuch Wezuwiusza, ominął nas widok czarnego anioła dżumy, i wściekły płomień, który pochłonął Giordana Bruna na

[Campo di Fiori, dawno skwierczy w Miłoszowym wierszu... [Wang 2020]

Spóźniliśmy się, stwierdza Wang, by być świadkami wielkich wydarzeń sprzed wieków; historia Bruna też jest już tylko (i aż) wierszem, ale (i więc) trzeba „mówić dalej” - o karetkach mknących ze świstem ulicami wspaniałego niegdyś miasta, jak „unoszą się / wioząc twój rozkołysany «ładunek», po raz ostatni w górę”, co do złudzenia przypomina końcową scenę z Biegnij, zającu.

\section{Przesuwanie akcentów. Miłosz pozostałych Intelektualistów}

Postanowiłam przyjrzeć się bliżej twórczości Wanga kosztem obszerniejszego omówienia dialogów innych poetów z Miłoszem, mimo że liczba esejów dotyczących polskiego noblisty oraz poetyckich nawiązań do jego twórczości u Wanga - na tle pozostałych Intelektualistów - wcale nie są nadzwyczaj imponujące. Jednak jego wyrazista retoryka oraz osobisty ton uwypuklają wiele cech ogólnej recepcji Miłosza w Chinach, a przykłady intertekstualności z ostatnich, covidowych, wierszy dowodzą trwałości tego odbiorczego paradygmatu. Choć i to nie są oczywiście jedyne dowody.

Ogromny wysyp w chińskim Internecie wierszy pandemijnych, z jakim mamy do czynienia od przełomu 2019 i 2020 roku, nie jest 
zaskoczeniem? ${ }^{9}$ W Chinach poezja traktowana jest w dużej mierze jako rodzaj społecznego komentarza, a często też praktyka towarzyska pośród osób chwytających za pióro jedynie amatorsko, którą Internet wydobył na światło dzienne. Każde z doniosłych wydarzeń, w szczególności zaś wielkie katastrofy naturalne, generuje w Państwie Środka poetyckie tsunami. W 2008 roku ogłoszono nawet konkurs na najlepszy wiersz o trzęsieniu ziemi w Wenchuan w Syczuanie ${ }^{10}$. Wówczas też rozgorzała jedna z najgorętszych dyskusji pośród „zawodowych” poetów, którą toczono wokół pytania, czy wolno w takich momentach uciekać się do poezji i czy warto to robić. Duża część argumentów krążyła wokół Holocaustu i słynnego pytania Theodora W. Adorna, czy po Oświęcimiu w ogóle da się jeszcze pisać poezję i czy jest to etycznie akceptowalne, część zaś wokół kwestii estetycznych - czy poezji służy bycie czystym dokumentem albo też, jak $w$ wielu przypadkach amatorskich wierszy, surowym zapisem emocji lub zlepkiem sentymentalnych fraz. Odpowiedzi znów zaczęto poszukiwać u europejskich poetów, w ich apokaliptycznym doświadczeniu. Zhang Shuguang i Sun Wenbo zgodnie powoływali się m.in. na Miłosza jako tego, któremu udało się jednocześnie pozostać świadkiem swojej epoki, nadać poezji indywidualny styl, nie uchybić kanonom językowego piękna oraz osiągnąć efekt uniwersalności poetyckiej refleksji, tak że pozostaje ona aktualna w kolejnych dekadach i w zgoła odmiennych okolicznościach [Lian 2016: 227-228].

Zhang i Sun rozumieją poezję Miłosza podobnie jak Wang, tyle że nieco inaczej rozkładają akcenty. Dla Zhanga słowami kluczowymi w interpretacji Miłosza, traktowanego przezeń jako poeta elegijny, są „czas” (shijian) i „ocalenie” (zhengjiu). Oba te aspekty stanowią jednak w istocie pochodną kategorii poetyckiego świadectwa, wysuwającej się na plan pierwszy u Wanga. W akapicie otwierającym esej Miłosz - śpiewak elegii (Miwoshi: wange de gezhe) czytamy:

Pokaźną kolekcję covidowej poezji można znaleźć na stronie internetowej MedSci [2020].

10 O poetyckim pokłosiu trzęsienia w Wenchuan pisze wyczerpująco Heather Inwood [2014: 168-176]. 
Całą twórczość poetycką Czesława Miłosza (1911-) można postrzegać jako wielką elegię, elegię o czasie. W obliczu czasu i tego, co się z nim wiąże - zmiany, zniszczenia, rzezi i śmierci Miłosz odczuwa przerażenie, zwątpienie, smutek, często wręcz bezsilność. Ale nigdy nie zapomina, że nie może porzucić swej poetyckiej odpowiedzialności. Próbuje spisać wszystko tak, jak było, jednocześnie jednak w jego wierszach nie brak pogłębionej refleksji nad naturą ludzką, historią i prawdą. [Zhang 2009]

Posługując się kluczem poety jako świadka, którego zadaniem jest utrzymanie ciągłości między czasem minionym a przyszłym, dobiera Zhang przykłady starannie omawianych w treści eseju utworów - pojawiają się w nim m.in. Spotkanie, Przedmowa, Kawiarnia, Pożegnanie, a także obszerne fragmenty Traktatu poetyckiego. Na podobnej zasadzie interpretuje autor również motyw wygnania obecny w biografii i twórczości Miłosza. Uwzględnia historyczny kontekst epoki, a jednocześnie stara się nadać Miłoszowej emigracji wznioślejszy wymiar. O ile Wang podkreśla dziejową konieczność, o tyle Zhang przekonuje, że Miłosz jako jeden z niewielu poetów żyjących na wygnaniu wcale nie był zmuszony do opuszczenia ojczyzny, lecz wyjechał u szczytu popularności, aby zyskać większą i spokojniejszą przestrzeń do pisania, a także lepszą perspektywę do obserwacji tego, co dzieje się w kraju. Jego krok był więc rodzajem ofiary złożonej nie tylko w imię poezji, ale i w imię narodu, który potrzebuje swojego rzecznika i kronikarza poza granicami kraju [Zhang 2009].

W 2001 roku ukazał się zbiór poezji Miłosza w przekładzie Zhang Shuguanga. Dobór utworów w tomiku, z dużą przewagą wierszy z okresu 1933-1980 i bardzo nielicznymi utworami nowszymi, w których problematyka odpowiedzialności historycznej stopniowo ustępuje miejsca tematom czysto metafizycznym, stanowi odzwierciedlenie tego specyficznego rozumienia poetyki Miłosza przez Zhanga. Jako drugi - po wyborze Lu Yuana - wydany w Chinach kontynentalnych zbiór utworów poetyckich polskiego noblisty, intensywnie czytany i komentowany w obozie Intelektualistów, przyczynił się do ugruntowania wśród Trzeciej Generacji takiego obrazu Miłosza. 
Pod względem poprawności i jakości artystycznej przekłady Zhang Shuguanga budzą wiele wątpliwości. Najbardziej bezpośrednio wyartykułowal je poeta i badacz Mei Shenyou w tekście Jeszcze przekłady czy juz handel narkotykami? (Shi fanyi, haishi fandu?), wytykając tłumaczowi błędy tak ewidentne, jak: pomylenie słowa mane („grzywa”) z name („imię”), potraktowanie mores („obyczaje”) jako (nieistniejącej) formy liczby mnogiej utworzonej od słowa more („więcej”) albo interpretację słowa iris jako „tęcza”, zupełnie nieprzystającą do kontekstu (chodziło o kwiat, który rozkwitał w dalszej części utworu). Pomyłki te doprowadziły do absurdalnych efektów końcowych [Mei 2007]. Zdarza się, że - jak na ironię - błędnie odczytane przez Zhanga zdania spotykają się ze szczególnym zainteresowaniem czytelników-komentatorów. Na przykład chętnie cytowane Studium samotności, kończące się w oryginale słowami: „Jeżeli ja jestem ludzkość, to czy ona jest sobą beze mnie? / I wiedzial, że na nic wołać, bo nikt z nich jego nie zbawi”, u Zhanga zawiera zgoła odmienną myśl, którą można by przetłumaczyć dosłownie: „Jeżeli ja jestem całą ludzkością, to czy pośród ludzkości jako takiej mnie nie ma”. Zdanie to przywołuje z zachwytem jako „niezapomniane” np. Sun w eseju, o którym mowa będzie za moment. Czy więc Miłosz, jakiego znają chińscy poeci, przynajmniej ci niewładający angielszczyzną, to faktycznie Miłosz, jakiego zna Polska i anglojęzyczny Zachód? Co więcej, Zhang stosuje dość nieelegancką składnię, odwzorowującą często niemal dokładnie składnię zdań angielskich. Takie tłumaczenie w języku chińskim powoduje dysonans estetyczny. Był on szczególnie wyczuwalny przez odbiorców, oswojonych już z nieco klasycyzującym, zwięzłym syntaktycznie i bardziej skondensowanym leksykalnie (posługującym się utartymi czteroznakowymi konstrukcjami i jednosylabowymi jednostkami semantycznymi) stylem Lu Yuana, wychowanego na wczesnej baihua, która w dużej mierze pozostawała jeszcze wierna „prawidłom wysokiego stylu”, by sięgnąć po określenie pożyczone od Miłosza. Wielu tłumaczy, w tym Mei, wyczuwa w języku Miłosza pewien rodzaj niemal niedzisiejszego dostojeństwa, co starają się oddać, wprowadzając do swoich przekładów elementy klasycznego języka chińskiego. Zhang raczej unika takiego zabiegu, być może 
aby dochować wierności długiej Miłoszowej frazie. Pod tym względem bowiem języki europejskie różnią się od chińskiego. Języki Starego Kontynentu niejako ewoluują w kierunku coraz większej oszczędności, a rozbudowana składnia sygnalizuje w nich niejednokrotnie archaiczne pochodzenie tekstu lub celową archaizację; język chiński natomiast dąży do rozluźnienia syntaktyczno-leksykalnego, a więc to, co dłuższe, jest z reguły nowsze - dlatego tak trudno pogodzić te dwie cechy Miłoszowego stylu w przekładach chińskich: język współczesny pozwala na zachowanie długiej frazy kosztem archaizującej elegancji, język klasyczny oddaje elegancję, ale jednocześnie skraca frazę.

W samej poezji Zhang Shuguanga oczywistych nawiązań do Miłosza jest stosunkowo niewiele, choć można by z pewnością obronić tezę o głębszym, strukturalnym wpływie jego poetyki na kształtowanie się stylu i postawy poetyckiej chińskiego autora. Samo nazwisko Miłosza, według ustaleń Liana, występuje w poezji Zhanga jeden raz, w wierszu Dekada (Shi nian), w którym podmiot liryczny wspomina po prostu, jak czytał wiersze noblisty „w tym domku blisko ulicy”. We Fragmentach (Duanzhang) z kolei w refleksji historiozoficznej pojawia się obraz płonących miast, Warszawy i Drezna, oraz świętego ognia trawiącego Joannę d’Arc i Giordana Bruna pośród okrzyków kramarzy, jak w Campo di Fiori [Lian 2016: 266].

W odróżnieniu od Zhang Shuguanga, Sun Wenbo większy nacisk niż na metafizyczny i historiozoficzny wymiar świadectwa kładzie na jego etyczny aspekt, i w tej perspektywie interpretuje też Miłosza. W Zapiskach z Shangyuan (Shangyuan zhaji), tłumacząc wybór swoich literackich mistrzów: Dantego, Du Fu, Miłosza i Brodskiego, mówi o tym wprost:

Ale dlaczego wybrałem właśnie ich? Czy dlatego, że piszą tak dobrze, lepiej od innych, na przykład od Li Baia, Hardy'ego, Frosta, Jimeneza? Otóż niekoniecznie. Wybierając ich, wybrałem pewną postawę i pewien sposób poznawania rzeczy. Jaka była postawa Miłosza? Stawiając opór wobec totalitaryzmu, jego poezja od początku do końca pełniła funkcję pamięci. [...] Interesuje mnie tak naprawdę to, jakie stanowisko przyjęli i jaką 
postawę obrali wobec własnego doświadczenia, w położeniu dalekim od idealnego. [cyt. za: Lian 2016: 181]

Nie jest oczywiście tak, że autorowi powyższych słów obojętne są inne aspekty twórczości Miłosza, w tym jej artystyczny walor. Sun Wenbo ma na swoim koncie dwa wnikliwe eseje poświęcone polskiemu poecie - pierwszy z nich to Poeta Cz. Miłosz (Shiren Qie Miwoshi), napisany krótko po śmierci noblisty, a drugi, dłuższy, Czytam Cz. Miłosza (Wo du Qie Miwoshi) pochodzi z 2010 roku. W pierwszym tekście chiński poeta koncentruje się przede wszystkim na moralności, przekonując m.in.:

W moim przekonaniu siła sumienia i moralności jest istotna w poezji, pozwala nam ona dobitniej odczuć znaczenie podstawowego porządku w życiu. Dziś wiele osób sądzi, że w poezji liczy się przede wszystkim nowa jakość będąca skutkiem rewolucji formalnej, ale u Miłosza dzieje się coś zupełnie innego. Sumienie i moralność stanowią istotę jego poezji. [Sun 2004]

W drugim z esejów zaś stosunkowo dużo miejsca poświęca autor umiejętności jasnego i precyzyjnego wyrażania myśli przez Miłosza, jego zdolności skupienia się na szczególe i wyprowadzenia z niego ponadczasowej wartości oraz pojemności, ekonomiczności i elegancji Miłoszowych form. Jako twórca, który w latach 90. zasłynął zwłaszcza z poezji narracyjnej, Sun Wenbo wyznaje, że są to techniki, które sam chciałby opanować. Jednocześnie jednak jest przekonany, że umiejętność zdyscyplinowanego i technicznie doskonałego pisania jest w dużej mierze funkcją nabytą poprzez osobiste doświadczenia i dzięki zdolności obserwacji:

Nigdy nie wierzyłem, że ktoś, kto nie widział choroby trawiącej istniejące rzeczy, może napisać nietuzinkowy wiersz. Powiem więcej: rzemiosło poetyckie to nie „czarcie sztuczki”, to sztuka poszukiwania najlepszej językowej formy wyrazu dla istoty rzeczy, do której poeta dociera. Jest więc oczywiste, że w owym medium uobecniają się i piękno, i cnota, i sprawiedliwość. [... $]$ 
Wielkość [poety - J.K.] to nic innego, jak wielkość ducha wielkości nie da się osiągnąć poprzez artyzm. [Sun 2010]

Sun, podobnie jak Wang i Zhang, kilkukrotnie przywołuje Miłosza również w konkretnych wierszach. Także u niego nawiązania te odzwierciedlają jego sposób lektury Miłoszowego dorobku. Przykładem może być poemat Zdjęcie z gazety (Xinwen tupian), który można odczytywać jako głos w toczącej się w latach 90. dyskusji nad dość powszechnym zjawiskiem „przebranżawiania się" poetów i porzucania przez nich działalności literackiej na rzecz komercyjnej. Był to skutek szybkiej transformacji ekonomicznej kraju dokonującej się przy jednoczesnych dużych ograniczeniach swobód twórczych, które wielu zniechęcały do pisania. Mottem do Zdjęcia ... czyni Sun wers z Gucia Zaczarowanego: „[... ] wolę przegrać, niż wygrać jak oni”. Cały zaś utwór jest opowieścią o poecie, który zatrudnił się w firmie, ale nie mógł tam znaleźć miejsca dla siebie, bowiem jego dusza „nie ustawała w poszukiwaniu wiecznej tajemnicy" [cyt. za: Lian 2016: 270]. W poemacie Przeprowadzka (Banjia) z kolei cytuje Sun jako motto początek Listu, poetyckiej rozmowy Miłosza z Radżą Rao: „Długie lata nie godziłem się / na miejsce, w którym byłem. Zdawało mi się, że powinienem / być gdzie indziej”. Bohater wiersza, jak Miłosz w liście do hinduskiego poety, poszukuje prawdziwego miasta, które jest zawsze „gdzie indziej”, „miasta prawdziwych drzew i głosów, przyjaźni i miłości” [Miłosz 2011: 599-60o]. Przekonany, że „dusza to synonim marzenia”, tworzy przy swojej fantasmagorycznej posesji „abstrakcyjny ogród” i „metaforyczny staw”. Ostatecznie ów współczesny Don Kichot, jak określa go narrator, staje się więźniem języka, który nie pozwala mu wznieść się na skrzydłach wyobraźni [Sun 1997].

Oprócz Zhang Shuguanga i Sun Wenbo o Miłoszu, dla Miłosza i „Miłoszem” pisali także inni Intelektualiści. Na przykład Song Lin, na stałe mieszkający we Francji, umieścił Miłosza w ramach konfucjańskiej filozofii poezji, cytując maksymę jej twórcy, definiującą jedną z czterech podstawowych funkcji poezji (obok pobudzania emocji, socjalizowania się i wnoszenia skarg do wyżej postawionych osób): shi keyi guan [Lian 2016: 176], co dosłownie oznacza „poezja może obserwować”, czyli przyglądać się społeczeństwu 
i komentować społeczny porządek. W przeddzień setnej rocznicy urodzin Miłosza Song zadedykował mu wiersz, który stylem przypomina nieco Odę na osiemdziesiąte urodziny Jana Pawta II i stanowi w dużej mierze skargę na stan współczesnej cywilizacji [Song 2014].

Wiersz zadedykował Miłoszowi także Wang Yin, tytułując swój utwór Błogostawieństwo - dla Czestawa Miłosza (Cifu - zhi Qiesiwafu Miwoshi). Jest to bodaj najwcześniejszy z chińskich utworów dedykowanych polskiemu nobliście, pochodzi bowiem z 1987 roku. Stanowi osobisty zapis dialogu z mistrzem, przed którym Wang „zasiada” w wyobraźni, wyznając mu: „ty jesteś trwalszy niż ja”, i kierując rozmowę na metafizyczne tematy dotyczące czasu i przemijania [Lian 2016: 277]. Wang Yin jest też autorem eseju Widziatem biata Polskę (Wo kanjian le baisede Bolan), będącego zapisem jego refleksji z podróży do Polski. Poeta przygląda się Polsce z zachwytem i respektem, oczyma Miłosza. Jednocześnie jednak bardzo mocno tkwi w charakterystycznej dla chińskich poetów wizji Polski jako kraju udręczonego, w którego literaturze dominuje pierwiastek tragiczny, brak zaś całkowicie pierwiastka komicznego. Hipotezę tę powtarza autor za słynną historią XIX-wiecznej literatury polskiej autorstwa Georga Brandesa [Wang 2006].

Wreszcie nie można też zapomnieć o Xi Chuanie, tłumaczu wielu wierszy Miłosza i współtłumaczu Abecadła (wraz z Bei Ta), który we wstępie do chińskiego wydania tomu dokonał bodaj najpełniejszej spośród wymienionych autorów analizy dorobku polskiego mistrza. Xi Chuan, jak otwarcie przyznaje, nie zna polskiego, a mimo to odważnie wypuszcza się nawet na niepewny grunt analizy cech charakterystycznych polszczyzny. Podąża za intuicją Witolda Gombrowicza, określając nasz język jako nieprecyzyjny i niesprzyjający refleksji filozoficznej, co jego zdaniem tym bardziej świadczy o geniuszu Miłosza, którego poezja udźwignęła ciężar takich rozważań [Xi Chuan 2014: 13-14]. Ocenę tej tezy pozostawiam Czytelnikowi. Pozwolę sobie jedynie dodać, że w porównaniu z chińskim, który nie posiada nawet gramatycznych wykładników czasu czy liczby, w niektórych obszarach polski jest wręcz skrajnie drobiazgowy.

Ogólnie rzecz biorąc, mimo bardzo dobrej orientacji Intelektualistów w poezji i biografii Miłosza, a także niezłej znajomości kon- 
tekstu historycznego jego twórczości, pozostaje on dla nich poetą jakby bezcielesnym, wyidealizowanym, przeżywającym rozterki, ale ostatecznie ze wszystkich wewnętrznych zmagań wychodzącym obronną ręką, w sposób godny naśladowania i cytowania; jest kimś w rodzaju wyroczni, której sądów się nie podważa. Jego odległa postać zaspokajała potrzebę mistrza, a Polska, jaką wyczytywali z jego wierszy, była abstrakcyjną matrycą, na którą można rzutować własną rzeczywistość, by przyjrzeć się jej w pomniejszeniu i z oddalenia, oraz własną traumę, by pomniejszyć ją i oddalić, a potem zmieścić w wierszu. Taki Miłosz i taka Polska, naładowana chińskimi traumami, stają się tłem cyklu Wierszy z Polskich Lei Pingyanga, poety młodszego o jedno literackie pokolenie od Intelektualistów, stojącego poza polemikami toczonymi wewnątrz Trzeciej Generacji i ich „młodzieżówek”, tj. swoich rówieśników identyfikujących się z jedną lub drugą frakcją. Lei, demontując pewien konstrukt Miłosza i Miłoszowej (rzekomo) Polski, jednocześnie przedstawia swoisty manifest zupełnie innej jakości poetyckiej, nieobecnej w twórczości przedstawicieli żadnego z dwóch skłóconych obozów, a zarazem bliższej duchowi poezji Miłosza niż nabożna lektura Intelektualistów.

\section{Cierpienie na oczach świata. Miłosz Lei Pingyanga i Lei Pingyang jako Miłosz}

Lei Pingyang, urodzony w 1966 roku, czyli roku wybuchu rewolucji kulturalnej, jest poetą pokolenia zwanego czasem Środkowym (zhongjiandai), choć termin ten używany jest stosunkowo rzadko i jedynie w odniesieniu do pięciu roczników (1965-1969). Urodzeni przed 1965 rokiem to bowiem zwykle Trzecia Generacja, a urodzeni od 1970 roku włącznie to Roczniki Siedemdziesiąte (7o hou). Pokolenie Środkowe ledwie otarło się o doświadczenia istotne dla przedstawicieli Trzeciej Generacji, których szkolna młodość przypadła na lata rewolucji, co wiązało się np. z powszechnym doświadczeniem reedukacji na wsi, a lata wczesnej dorosłości, będące w wielu przypadkach początkiem kariery akademickiej, naznaczone były tragedią Tian'anmen. Literacko dojrzewało jednak karmione w poezji owymi traumami. 
Lei od początku trzymał się niejako na uboczu, z dala od dyskusji i konfliktów rozgrywających się na pierwszej linii sceny poetyckiej, tematem swoich wierszy i esejów czyniąc przede wszystkim lokalną społeczność oraz przyrodę rodzimej prowincji Yunnan, etnicznie różnorodnej i znanej z pięknych górskich krajobrazów. Choć jego utwory wydawać się mogą niekiedy naturalistycznymi portretami rzeczy i zjawisk, kryje się w nich w istocie głęboka czułość, nostalgia oraz bezkompromisowa krytyka cywilizacji. Dlatego też Lei zarzuca niezrozumienie tym, którzy nazywają go realistą albo „poetą lokalnym/lokalności” (difangxing). Jego najbardziej znanym wierszem jest wstrząsający Proces ukatrupiania psa (Sha gou de guocheng), opisujący zabijanie zwierzęcia „na raty”, w pięciu podejściach, przez 55 minut między 10.25 a 11.20, na oczach gapiów zgromadzonych na targowisku [Lei 2015: 16-17]. Niewykluczone, że za tym wierszem, powstałym prawdopodobnie na przełomie stuleci, kryją się inspiracje Różewiczowskie, a jeśli nie inspiracje, to przynajmniej pokrewieństwo wyobraźni, potwierdzone późniejszym odkryciem przez Leia reportaży Tadeusza Różewicza z Chin i Mongolii, gdzie polski poeta w latach 5o. obserwował zabijanie baranka, oraz być może jego Bieli, opisującej tenże proces w odniesieniu do baranka wielkanocnego. W powstałej po 2010 roku Bezsenności (Shimianzheng) pisze z ironicznym wyrzutem skierowanym bardziej niż do Różewicza do „nas”, czyli Chińczyków:

$[\ldots]$

Nienawidzimy tego Polaka, nie powinien

w języku polskim wypowiadać intertekstualności tragedii

[i komedii

nie powinien wierszem podkreślać codzienności

i powszechności końca świata

$[\ldots]$

[Lei 2015: 252]

Mówiąc „nie powinien”, Lei akcentuje dyskomfort, jaki poezja Różewicza wywołuje w odbiorcy, a jednocześnie także definiuje swoją poetykę, która polega nie tyle na rozdrapywaniu blizn, ile na odsłanianiu ran, których ludzkość nawet nie jest świadoma, a które niebezpiecznie 
jątrzą się w jej łonie. Jakby w odwecie, przybywszy do Polski, Lei na warszawskiej ulicy dokonuje w myślach mordu na gołębiu:

[...] Wszystko dzieje się teraz, nikt nie wie, gdzie przebiega granica koszmaru, ja zaś jak w realu sypię sól do rany. Moi poplecznicy, o posrebrzanych włosach, gdy tylko nadarza się okazja, wspominają przy wódce socjalizm. „Kula przebiła serce, zaraz wyfrunie z ciała”. Żeby poruszyć młode pokolenie, łopatą przebijam wyimaginowanego gołębia na placu. Ludzie żegnają się śmiertelnie przerażeni. „Kula wyleciała z ciała, została śmierć!” Początkowo chciałem opisać jeszcze śmierć duszy, ale powstrzymałem się. W ich oczach i tak gorszy jestem nawet od nazistów.

Naziści kazali im umrzeć raz, a ja przed zmartwychwstaniem każę im konać ponownie. Tymczasem oni chcieliby pożyć, nie chcą raz za razem bez wytchnienia umierać z wiecznej nienawiści [Lei 2015: 223]

Z jednej strony Lei czuje się przytłoczony martyrologią, którą w jego odczuciu epatują polskie miasta - widok rzeźb, ołtarzy, krzyży niemal obezwładnia jego wyobraźnię, sprawia, że poeta chce co prędzej uciec z Polski, bo czuje, jak jego ciało „przerzeźbia się w krzyż”, czuje, że daje się ponieść cudzej śmierci, że staje się pomnikiem. Z drugiej strony jednak w żaden sposób nie neguje ogromu cierpienia. Rozprawia się raczej z jakąś jego romantyczną wizją, która prowadzi do uniesień i do odrealnienia bólu oraz przepisywania go z języka na język (jak w Bezsenności męczarnie zwierzęcia w Mongolii przepisane zostały na język polski), tak że stopniowo traci on ostrość. Tak samo traci ostrość historia Polski w przekładzie językowym i kulturowym, przefiltrowana przez twórczość Miłosza, specyficznie zinterpretowaną przez chińskich poetów, staje się nieledwie ramą kompozycyjną dla cudzych traum. W wierszu Do Miłosza (Zhi Miwoshi) Lei kieruje do adresata niejednoznaczny komunikat: 
Zawsze podziwiałem Czesława Miłosza

nie ze względu na jego dzieła

lecz na to że zdołał przez całe życie

trzymać się z dala od tego kraju

jego wiersze zaś były odłamkami ojczyzny

W tym kraju, po dziś dzień sadzą ziemniaki w ranach

czy boli? Chciał, żeby kraj ten wiecznie cierpiał

cierpiał na pokaz przed światem

trochę jak ten Święty na krzyżu

kilkoma gwoźdźmi można unieruchomić

wiarę, powiesić na wieki.

[Lei 2011 $]^{11}$

Na pierwszy rzut oka wiersz wydaje się ostrą krytyką odzianą w płaszcz ironii zaprawionej komizmem, czym zresztą od razu Lei zadaje kłam tezom Intelektualistów, jakoby o Polsce można było pisać tylko w kategoriach tragicznych. Oto Miłosz, sadysta, z zimną krwią handlujący romantyczną martyrologią, odmalowuje dzieje Polski niczym stacje drogi krzyżowej i sprzedaje za symboliczny kapitał do literackich galerii. Jednocześnie jednak Lei czuje, że sam przecież robi to samo, jego podziw dla Miłosza nie jest do końca ironiczny, jeśli - to raczej autoironiczny. On też przecież chodzi po rodzimej ziemi i widzi otwarte rany tam, gdzie inni widzą dobrze użyźnioną glebę, doskonałą pod uprawy, i poprzez poezję mówi o tych ranach, daje świadectwo, wystawiając się na kpiny i lekceważenie.

Miłosz, jak wielu polskich poetów, także tych największych, miał poczucie własnej śmieszności. Wszyscy oni uporczywie oglądali w lustrze - by powtórzyć za Zbigniewem Herbertem - „swoje błazeńskie twarze”, pytając, „czy nie było lepszych”. Ta świadomość ważności i niewdzięczności zadania w połączeniu z doświadczeniem cudzej niewiedzy i własnej niemocy wpędzała ich w irracjonalne wręcz poczucie winy i groteskowości, które nijak ma się do ich

Wiersz pochodzi z tego samego cyklu, nie został jednak włączony do tomu, z którego cytuję pozostałe utwory z Wierszy z Polski. Do Mitosza opublikowany był wcześniej na blogu poety, obecnie jednak dostęp jest zablokowany; skopiowany tekst można przeczytać na innym blogu. 
odrealnionych, pomnikowych sylwetek funkcjonujących w świadomości chińskich odbiorców - i nie tylko. Nijak ma się też do potrzeb, które pragnie zaspokoić ich twórczością Trzecia Generacja, i do jej nieprzepartej „woli mocy” - tęsknoty do monumentalnych, wiekopomnych form i do wizerunku poety jako duchowego przywódcy, w którego nie tylko inni nie zwątpią, ale przede wszystkim który sam w siebie nie będzie wątpił. Przez całe lata 80. i 90., choć i później, chińska scena poetycka stanowiła arenę zmagań o pozycję, ustanawiania hierarchii i stosunków sił. Poeci skupiali się na udowadnianiu własnej racji, a nie kontemplowaniu jej potencjalnego braku. Lei zdecydowanie wyłamuje się z tego schematu.

Huo Junming, poeta, krytyk i literaturoznawca, prywatnie przyjaźniący się z Leiem, kojarzy postawę i poetykę Leia z Miłoszem poprzez kategorię wstydu (xiuchi) jako czynnika determinującego postrzeganie własnej roli i miejsca w świecie przez obu poetów. Huo, tak jak przywoływani wcześniej autorzy, również mówi o postawie świadka, jednocześnie jednak starając się ukazać jej wewnętrzną złożoność, która nie polega jedynie na tym, by utrzymać optymalny dystans do zdarzeń - by nie stracić z nimi łączności, a jednocześnie móc opisać je z zewnątrz - ale też na tym, by w ogromie przytłaczających wypadków nie stracić łączności z samym sobą i z duchowym wymiarem egzystencji. Krytyk w ostrych słowach opowiada o „zniewolonych umysłach” wielu współczesnych poetów, o „obniżającej się duchowej trudności” ich wierszy, o ich homogenizacji, o fałszywych „ofiarach” i „pseudokościołach” wznoszonych przez nich na poetyckiej scenie, o „myślowych plwocinach” oraz ogólnym samozadowoleniu i pysze, której pełno w ich wierszach i wypowiedziach. Brak w nich zaś, jego zdaniem, samokontroli, samoświadomości, samostanowienia, autorefleksji, jakiegokolwiek poczucia winy i wyrzutów sumienia. Dla kontrastu Huo [2020: 127-128] przywołuje słowa Miłosza, który niejednokrotnie wyznawał, że tożsamość poety napawa go wstydem, że czuje się jak nagi człowiek wystawiony publicznie na pokaz. Można by w tym miejscu przypomnieć także słynną Ars Poetica?, w której trzeciej strofie czytamy dokładnie o tym, o czym mówi chiński krytyk, a więc o wstydliwych, intymno-mistycznych źródłach poezji: 
Dlatego słusznie się mówi, że dyktuje poezję dajmonion, choć przesadza się utrzymując, że jest na pewno aniołem. Trudno pojąć skąd się bierze ta duma poetów jeżeli wstyd im nieraz, że widać ich słabość. [Miłosz 2011: 588]

To trochę jak ze stygmatami: ci, u których są one autentyczne, zwykle wstydzą się o tym mówić i ukrywają rany pod szatą. Oszuści, którzy chcą zyskać poklask, obnoszą się z okaleczeniami.

Huo Junming dostrzega u Leia taki właśnie rodzaj autentyczności poetyckiego powołania. Porównując go z Miłoszem, stwierdza:

Lei Pingyang również spogląda na rzeczywistość okiem świadka, spisuje raporty z miejsca zdarzeń. Co jednak ważniejsze, poprzez swoje przypowieści przypominające śnienie w biały dzień, poruszające problemy człowieka, ludzkiej natury, rzeczywistości, czasu, przestrzeni, historii, konstruuje poetykę wstydu. Wstyd bierze się przede wszystkim z uczciwego spojrzenia na siebie samego, a w drugiej kolejności z własnego nieprzystawania i niedopasowania do otoczenia, do ludzi i epoki. [Huo 2020: 127-128]

Na potwierdzenie tych słów Huo przywołuje fragment z eseju Leia $W$ górach Wencheng (Zai Wencheng Shan zhong), który pozwolę sobie przytoczyć, idąc za jego przykładem, by dać Czytelnikowi lepsze wyobrażenie o twórczości chińskiego poety. Warto też zwrócić uwagę na zbieżność klimatu jego prozy z prozą wspomnieniową Miłosza, czy to z jego eseistyką, czy z prozatorskimi fragmentami poematów, czy wreszcie z Doliną Issy. We wcześniejszym artykule, poświęconym prozie Leia, Huo [2019] również powolywał się na dzieło Miłosza jako wyznacznik pewnego sposobu myślenia o lokalności w literaturze. Oto próbka eseistyki „chińskiego Miłosza”:

Urodziłem się w górach Yunnanu, mam ponad czterdzieści lat i dotąd nie opuścilem tego miejsca. Powody są następujące: po pierwsze, jak okiem sięgnąć, panuje tu spokój, nie trzeba się nigdzie spieszyć, przed niczym drżeć, zaciskać pięści; po drugie, 
mieszkając w zagajniku przyświątynnym, co dzień słuchać można łagodnego dźwięku modlitw, ma się widok na pagodę i kaszaje przechadzających się wokół mnichów; po trzecie, w studni, którą opiekuje się moja matka, nadal jest chłodna, słodka woda, a w Święto Czystości i Jasności pochowani w górach zmarli nadal powracają na wspólny posiłek... Wiem, takie powody bardziej pasowałyby do ludzi sprzed sześciuset lat. Dziś mówić o nich mogę jedynie pod osłoną nocy, w miejscu bezludnym, bez światel, albo gdy ludzie pozatykają uszy, a noc pochłonie ich zdziwione spojrzenia i uprowadzi w sen. Gdybym miał powiedzieć o tym, stojąc przed publicznością w auli, do słuchawki albo do kamery, wzięto by mnie za kłamcę albo za dziedzica dawno obalonej dynastii. To bardzo bolesne, jakby jakaś wszechobecna siła wydzierała mi wolność słowa. A ja się jej poddaję, myśląc niepewnie, że powiedzieć o tych powodach, to byłby wstyd. Człowiek jest chory, czy Niebo o tym wie? A jednak, ciągle o tym mówię. Głos wychodzi z płuc, wędruje przez gardło, w końcu przy drżeniu języka wydostaje się na zewnątrz i mknie do świata. [cyt. za: Huo 2020: 128]

Pojawiające się w treści dość zaskakujące pytanie: „Człowiek jest chory, czy Niebo o tym wie?” (Ren you bing, tian zhi fou?) można także przetłumaczyć jako: „Jestem chory, czy Niebo o tym wie?” albo „Gdy czlowiek jest chory, czy Niebo o tym wie?”. To cytat z wiersza Mao Zedonga Na melodię „He xinlang” ${ }^{\prime \prime 2}$ napisanego na pożegnanie jego pierwszej żony Yang Kaihui w 1923 roku, kiedy to para, mająca już wtedy dwójkę malutkich dzieci, musiała się rozstać, gdyż Mao został wezwany do pracy na rzecz rewolucji z dala od domu. W wierszu mówi on o tym, że odtąd losem jego będzie życie w samotności, pośród wiecznej tułaczki. Co jednak dość intrygujące, wers ten został dopisany dokładnie 50 lat później, zamiast wersu opisującego padający deszcz, a ujawniono go dopiero po śmierci autora. Nie wiadomo, o jaką konkretnie chorobę chodziło czy o chorobę jednostkową, czy o chorobę rodzaju ludzkiego, choć osobisty ton wiersza wskazuje, że raczej o tę pierwszą. Być może, 
jak spekulują niektórzy, Mao pisał o swoich problemach psychicznych, o których w Chinach w latach 70. Xx wieku publicznie się nie mówiło (od tego czasu zresztą niewiele się zmieniło), bowiem stanowily one najbardziej wstydliwe tabu ${ }^{13}$. W każdym razie można przypuszczać, że w takim właśnie znaczeniu przywołuje ten cytat Lei, wskazując tym samym na poezję jako stan bliski obłędowi. Nie chodzi tu jednak bynajmniej o romantyczny obłęd świętych szaleńców, który inscenizują chętnie w swoich utworach wspólcześni poeci dla większego splendoru, ale o trawiącą człowieka od środka chorobę, do której woleliby się nie przyznawać przed światem ani przed Niebem. Albo może właśnie w Niebie szukają ukojenia i zrozumienia, którego nie mogą zaznać u ludzi?

Tak czy inaczej, rzecz oczywiście nie w tym, by upatrywać w Leiu chińskiego wcielenia Miłosza (ani tym bardziej współczesnego Mao Zedonga), lecz by zwrócić uwagę na pewien typ poetyckiej, i ludzkiej, wrażliwości, który w poezji tzw. polskiej szkoły, w tym Wielkiej Czwórki, był silnie obecny, a który zwykle umyka w interpretacjach ich twórczości - nie tylko w Chinach, ale w ogóle na świecie. Identyfikacja tej wrażliwości u Miłosza przez Huo i celne, jak sądzę, określenie jej mianem poetyki wstydu, to fakty same w sobie godne uwagi, podobnie jak pomysł poszukiwania tejże wrażliwości u poety, który nie daje w swoich utworach bezpośrednich wskazówek czytelnikowi, by podążał tropem Starych Mistrzów, tak jak dzieje się to w przypadku Intelektualistów, słynących z tworzenia długich litanii wielkich nazwisk. Przeciwnie, Lei myli tropy, komplikuje sądy, wysyła odbiorcy sprzeczne impulsy, często niepozwalające odróżnić (auto)ironii od pisania wprost.

Być może, biorąc pod uwagę uznanie, jakim cieszy się twórczość Leia, jest to sygnał jakiegoś zwrotu w myśleniu o poezji w Chinach - już nie w kategoriach walki o dominację na poetyckiej scenie i prawo do definiowania reguł poetyckiego rzemiosła, ale w kategoriach pracy wewnętrznej, mierzenia się z samym sobą, przyzwolenia na własną słabość. A także poniekąd sygnał uwalniania się przez nią od tego, co niektórzy nazywają „kompleksem gwenda [2020] i Tianyawenguan [2020]. 
Zachodu” (Xifang qingjie), a co przejawia się w przyjmowaniu wszystkiego, co przychodzi w formie poetyckiej zza zachodniej granicy, za dzieła mniej lub bardziej kanoniczne, traktowane jako uniwersalne wzorce, czy to literackich technik, czy etycznych postaw, bez przekonujących prób wniknięcia w skomplikowaną psychologiczno-duchową tkankę tekstów.

To, co powiem na zakończenie tej części, nie jest argumentem stricte naukowym, a jedynie stanowi pewien szczęśliwy zbieg okoliczności. Niemniej w jakiś sposób desubiektywizuje on intuicję Huo Junminga, by połączyć Leia z Miłoszem. Przygotowując monografię poświęconą poezji polskiej i chińskiej, w podrozdziale omawiającym Wiersze z Polski Leia - szkic tekstu powstał pod koniec 2019 roku - wyraziłam przypuszczenie, że Do Miłosza jest bardziej przekonującym hołdem złożonym Miłoszowi niż wiersze Intelektualistów i wydaje się bliższy Miłoszowemu rozumieniu poezji. Na artykuł Huo, opublikowany w numerze 3 z roku 2020 czasopisma „Dianchi”, natrafiłam zaś dopiero kilka miesięcy później. Byłam zaskoczona tą zbieżnością, ale zarazem utwierdzona w swoim niejasnym przeczuciu; jednocześnie z góry obdarzyłam wywód Huo dość dużą dozą zaufania, którego we wspomnianym tekście nie zawiódł w najmniejszym stopniu. Ostatecznie, jeśli dwom osobom o tak odmiennych doświadczeniach lekturowych i kulturowych, czytających w dwóch różnych językach, nasuwa się podobne skojarzenie, rzecz wydaje się przynajmniej warta dalszego zgłębienia, a na pewno - dalszej obserwacji, w miarę ewoluowania poezji Leia, a także przemian chińskiego dyskursu poetyckiego jako takiego.

\section{Inni Miłosze}

Choć to Intelektualiści w dużej mierze ukształtowali wizerunek Miłosza w Chinach, nie jest oczywiście tak, że innym poetom Miłosz pozostał obcy lub obojętny. Niewiele nawiązań do jego twórczości znajdziemy u samych Ludowców, ale już w drugim pokoleniu ukształtowanym przez poetykę tej frakcji o polskim nobliście mówi się znacznie chętniej. Przedstawicielami tej frakcji są np. Duo Yu (ur. 1973), autor starannie skrojonego, wyważonego 
eseju biograficznego o Miłoszu oraz wiersza Niegdyś - dla Miłosza (Cengjing - zhi Miwoshi), wcześniej jeden z najaktywniejszych członków grupy Poetów Dolnej Połowy Ciała (Xiabanshen shiren), retorycznej „bojówki” obozu Ludowców, oraz Yi Sha (ur. 1966), rówieśnik Lei Pingyanga, niestrudzony polemista, sypiący inwektywami jak z rękawa, który w ostatniej dekadzie zwrócił się ku Starym Mistrzom i postanowił przełożyć „po swojemu” kanon poezji światowej, w tym m.in. Dar Miłosza.

Przedsięwzięcie Yi Sha jest interesujące, gdyż stanowi próbę „odbicia” klasyków Intelektualistom. Yi Sha, sam niewładający biegle angielskim, w procesie tłumaczenia korzystał z językowej wiedzy swojej żony Lao G. Brak kompetencji językowych nie przeszkadzał mu przy tym ostro krytykować istniejących przekładów poetów zagranicznych, którym zarzucał błędy merytoryczne i stylistyczne nadęcie. W książce Kiedy jesteś stary (Dang ni lao le), której tytuł nawiązuje do wiersza Yeatsa, Yi Sha zebrał własne alternatywne wersje 100 utworów ze światowej klasyki, przełożonych na raczej potoczny, niewygładzony, niekiedy kulejący składniowo chiński, w sposób ujednoznaczniający i ukonkretniający przekaz. We wcześniejszym artykule omawiałam jego przekład Fugi śmierci Celana, pokazując, jak dokładnie przebiega ten proces konkretyzacji w tekście i jakie techniki stosuje Yi Sha, by przeciągnąć zastępczych ojców i matki na swoją stronę [Krenz 2019a]. Podobną transformację przechodzi pod jego piórem Dar [Yi i Lao G 2013: 3], który w porównaniu z przekładami autorstwa innych poetów w wykonaniu Yi Sha momentami bardziej może przypominać utwór o robotach drogowych niż o pracy w ogrodzie, co oczywiście niekoniecznie musi być zarzutem, skoro taka właśnie była eksperymentalna intencja tłumacza.

W licznych przekładach Daru ${ }^{14}$, które krążą w Internecie, przechwytywane przez kolejnych blogerów i użytkowników forów, odmalowany jest cały krajobraz chińskiej sceny poetyckiej. Cechy własnej twórczości, postulaty poetologiczne i preferencje estetyczne poetów-tłumaczy widać w nich niemal jak na dłoni. Elegancki i wyważony przekład Xi Chuana w tym wypadku w moim 
przekonaniu najlepiej ujmuje istotę wiersza. Xi Chuan jakby starał się uchwycić tę rzekomą niefilozoficzną nieprecyzyjność polszczyzny, co widać w jego zgrabnym tłumaczeniu wersu: „Nie wstydziłem się myśleć, że byłem kim jestem”, oddanego za pomocą skondensowanej klasycyzującej składni. W porównaniu z tą wersją tłumaczenie Zhang Shuguanga, z „rozciągniętą” składnią i wyostrzonymi emocjami (oddanymi np. poprzez użycie mocniejszych słów oznaczających zazdrość i wstyd w języku chińskim) wydaje się zakłócać nastrój pogodnego zamyślenia obecnego w Darze, jakby Zhang chciał dodać utworowi dramatyzmu i uwznioślić go, do czego też ma tendencje jako poeta. Z kolei Shen Rui, prywatnie była żona Wang Jiaxina, obecnie mieszkająca w Stanach Zjednoczonych, ubarwia przekaz, uzupełniając szczegóły (kolibry w jej przekładzie śpiewają nad kwiatem kapryfolium) i wzmacniając przeczenia poprzez zastosowanie dłuższych form (np. ,jakiejkolwiek rzeczy” [shenmeyangde dongxi] w miejsce Miłoszowej „żadnej rzeczy”), co również w pewnej mierze koreluje z żywym stylem widocznym w szczególności w komentarzach krytycznoliterackich jej autorstwa. Pośród tłumaczeń jest też m.in. anonimowa wersja Daru z wkomponowanym wulgaryzmem, odpowiednikiem najpowszechniejszego polskiego przecinka. Na tle kontynentalnych wariacji na temat tego wiersza - skądinąd bardzo solidny, w mojej ocenie porównywalny z Xi Chuanowym - tajwański przekład Du Guoqinga przedstawia spokojny, emocjonalnie zbalansowany krajobraz, który jednak tchnie jakąś surowością. Przy tym należy oczywiście uczciwie dodać, że może to być wyłącznie subiektywne odczucie, trudno bowiem tę intuicję skonkretyzować na podstawie samej tylko analizy składniowej czy leksykalnej.

Przekład najdobitniej pokazuje, że nie ma jednego Miłosza każdy ma takiego poetę, jakiego sobie wypracował. Gdzie kończy się interpretacja, a zaczyna manipulacja, to oczywiście zupełnie inna kwestia, do rozważenia w literackim sumieniu każdego z tłumaczy czy komentatorów jego twórczości. Najważniejsze jednak, że jest to Miłosz cały czas żywy, cały czas mający coś do zaoferowania coraz to młodszym czytelnikom z coraz to odleglejszych krajów. Ten, który sam sobie będąc tytułowym Oskarżycielem, wróżył, że po śmierci będzie tylko hasłem w czternastym tomie encyklopedii 
w pobliżu Myszki Mickey i setki Millerów [Miłosz 2011: 671], a w/ na Capri deklarowal, że odchodzi razem ze swoją epoką, gotów na wyrok, który go „policzy między jej fantomy” [Miłosz 2011: 1056], okazuje się poetą wiecznie aktualnym i wiecznie potrzebnym. Jako przybrany ojciec wiele dobrego już uczynił dla chińskiej poezji, przynosząc jej nadzieję, pokrzepienie, wiarę w sens, poczucie celu, a teraz stopniowo udziela coraz to trudniejszych lekcji: wstydu, pokory, mądrego wątpienia. Jest to, rzecz jasna, lekcja, która przyda się nie tylko poezji chińskiej i nie tylko poezji w ogóle, lecz także wszystkim jej faktycznym i potencjalnym odbiorcom. Ostatecznie przecież więcej nas wszystkich łączy, niż dzieli, jak pięknie ujął to niegdyś sam Miłosz w wierszu A jednak:

A jednak byliśmy do siebie tak podobni

$\mathrm{Z}$ całą naszą mizerią penisów i wagin.

$\mathrm{Z}$ bijącym mocno sercem w strachu i rozkoszy,

I nadzieją, nadzieją, nadzieją.

A jednak byliśmy do siebie tak podobni, Że leniwe smoki przeciągające się w powietrzu Musiały nas uważać za braci i siostry

Bawiących się zgodnie w słonecznym ogrodzie, Tylko my o tym nie wiedzieliśmy,

Zamknięci każde w swojej skórze, osobni, I nie w ogrodzie, na gorzkiej ziemi.

A jednak byliśmy do siebie tak podobni, Mimo że każde źdźbło trawy miało własny los, Każdy wróbel w podwórzu, każda mysz polna.

A niemowlę, które dostanie na imię może Jan, może Teresa, Rodziło się na długie szczęście albo na wstyd i cierpienie Tylko raz jeden, aż do końca świata.

[Miłosz 2011: 989] 


\section{Bibliografia}

Chen Xuan (2013), Ai Qing yu Huiteman shige bijiao yanjiu [Poezja Ai Qinga $i$ Walta Whitmana $w$ perspektywie komparatystycznej], Uniwersytet Studiów Zagranicznych w Xianie, [rozprawa doktorska].

Cheng Gunagwei (1998), Bu zhi suo zhong de lüxing - jiushi niandai shige zonglun [Podróż o nieznanym celu - o poezji lat 9o.], [Wstęp (do antologii poezji)], w: Suiyue de yizhao - jiushi niandai wenxue shuxi, red. Cheng Guangwei, Shehui Kexue Wenxian, [pierwodruk], [dostęp: 5 września 2020], https://tinyurl.com/7rzx78h4 [wydanie internetowe].

Cheng Guangwei (1999), Ai Qing zhuan [Biografia Ai Qinga], Shiyue Wenxue Chubanshe, Pekin.

van Crevel Maghiel (2008), Chinese Poetry in Times of Mind, Mayhem and Money, Brill, Leiden.

Gao Hua (2009), Du Mao Zedong shici 'Ren you bing, tian zhi fou?' [Odczytanie wiersza Mao Zedonga „Człowiek jest chory, czy Niebo o tym wie?”], [dostęp: 5 września 2020], https://tinyurl.com/y94zcwxt.

Haizi (1986), Shixue - yi fen tigang [Poetyka-zarys], w: Haizi shi quanbian [Wiersze wszystkie Haizi], red. Xi Chuan, [dostęp: 5 września 2020], https://tinyurl.com/ybma7z45.

Huang Guiyou (1997), Whitmanism, Imagism, and Modernism in China and America, Susquehanna UP, Associated UP, Selinsgrove-London.

Huang Guiyou (1998), A Newer Realm of Poetry: Whitman and Ai Qing, „Walt Whitman Quarterly Review”, z. 15, s. 172-179.

Huo Junming (2019), Lei Pingyang: Liushi ge roushen huo tishen [Lei Pingyang: Szesnaście ciał lub wcieleń], „Shanhua”, z. 8, s. 104-112.

Huo Junming (2020), Shui shi Lei Pingyang? [Kim jest Lei Pingyang?], „Dianchi”, z. 3, s. 120-128.

Inwood Heather (2014), Verse Going Viral: China's New Media Scenes, University of Washington Press, Seattle-London.

Jiang Dengke i Li Shengyong (2015), Dui 'menglong shi lunzheng' zhong Ai Qing lichang de chongxin shenshi [Ponowne spojrzenie na stanowisko Ai Qinga w sporze o Poezję Mglista], „Chongqing Daxue Xuebao (Shehui kexue ban)” [„Czasopismo Uniwersytetu w Chongqingu (Nauki Spoleczne)"], z. 1 (21), s. 164-17o.

Jianshu (2020), [dostęp: 5 września 2020], https://tinyurl.com/2w8eejpz.

Jingren (1982), Miwoshi de 'Guguo' [Rodzinna Europa Mitosza], „Dushu” [„Czytanie”], z. 8, s. 151. 
Krenz Joanna (2017), Wstęp tłumaczki, w: Yu Jian, Świecie wejdź / Shijie a ni jinlai ba, Dialog, Warszawa, s. 13-38.

Krenz Joanna (2018), Narodziny awangardy. Lata osiemdziesiąte jako dekada zwrotna w poezji chińskiej, „Porównania”, t. 23, nr 2, s. 297-316, https://doi.org/10.14746/p.2018.23.18713.

Krenz Joanna (2019a), Celan's "Deathfugue" in Chinese: A Polemic about Translation and Everything Else", w: Chinese Poetry and Translation: Rights and Wrongs, red. Maghiel van Crevel i Lucas Klein, Amsterdam UP, Amsterdam, s. 287-308.

Krenz Joanna (2019b), Oświęcim, tani chleb i ziemniaki w ranach. Polska oczami chińskich poetów, „Porównania”, t. 24, nr 1, s. 213-230, https://doi.org/10.14746/por.2019.1.17.

Lei Pingyang (2011), Zhi Miwoshi [Do Mitosza], Sixuan de boke [blog Sixuan - pierwsze miejsce publikacji], [dostęp: 5 września 2020], https://tinyurl.com/2adt8hrz [obecnie jedyne miejsce dostępu tekstu].

Lei Pingyang (2015), Shanshuike [Lekcja krajobrazu], Zuojia Chubanshe, Pekin.

Li Runxia (2005), Yi Aiqing yu qingnian shiren de guanxi wei li chongping 'menglong shi lunzheng' [Reewaluacja sporu wokót Poezji Mglistej przez pryzmat relacji między Ai Qingiem a młodszymi poetami], „Xiandai Wenxue Yanjiu Zongkan” [„Badania nad Literaturą Współczesną”], Z. 3, s. 178-202.

Li Yinan (2016), Recepcja literatury polskiej w Chinach: teoria i dzieje, „Postscriptum Polonistyczne”, nr 2 (18), s. 171-185, [dostęp: 6 maja 2021], https://tinyurl.com/smhjk.

Lian Hansheng (2016), Zai 'jianzheng' yu 'yuyue' zhijian - Miwoshi, Buluociji he Xini yu Zhongguo dangdai shige [Między „świadectwem” a "radościa”. Miłosz, Brodski i Heaney a wspótczesna poezja chińska], Uniwersytet Ludowy w Pekinie, [rozprawa doktorska].

MedSci (2020), [dostęp: 5 września 2020], https://tinyurl.com/28sp6eez.

Mei Shenyou (2007), Shi fanyi, haishi fandu? [Jeszcze przekłady czy już handel narkotykami?], „Douban Dushu” [„Douban: Lektury”], [dostęp: 5 września 2020], https://tinyurl.com/33vbb3fp.

Miłosz Czesław (1983), The Witness of Poetry, Harvard up, Cambridge.

Miłosz Czesław (2005), Przekłady poetyckie, Znak, Kraków.

Miłosz Czesław (2011), Wiersze wszystkie, Znak, Kraków.

Ming Di (2016), A Survey of Poets' Favorites, Chinese \& Western:

Ten Chinese poets share their influences, [dostęp: 5 września 2020], https://tinyurl.com/ros25pe4. 
van Nieukerken Arent (2012), Czestaw Miłosz i Walt Whitman: przekład jako prawdziwa obecność, „Poznańskie Studia Polonistyczne. Seria Literacka”, nr 20 (40), s. 217-231.

Skwara Marta (2004), Whitman „wielki realista: - Miłosza projekt portretu autorskiego, „Teksty Drugie”, z. 4, s. 56-73.

Song Lin (2014), Zhi Miwoshi [Do Miłosza], „Xibu” [„Zachód”], z. 11, s. 6.

Sun Wenbo (1997), Banjia [Przeprowadzka], w: tejże, Ditu shang de lüxing [Palcem po mapie], Gaige Chubanshe, Pekin, s. 33 .

Sun Wenbo (2004), Shiren Qie Miwoshi [Poeta Cz. Miłosz], „Zhongguo Nanfang Yishu”[„Sztuka Południowochińska”], [dostęp: 5 września 2020], https://tinyurl.com/j22u5597.

Sun Wenbo (2010), Wo du Qie Miwoshi [Czytam Cz. Miłosza], w: Zai xiangduixing zhong xiezuo [Pisanie wśród relatywizmu], [pierwodruk], Xiandai shixuancui [Najlepsze teksty o/ze wspótczesnej poezji, [blog], [dostęp: 5 września 2020], https://tinyurl.com/446k2umm, [wydanie internetowe].

Tianyawenguan (2020), [dostęp: 5 września 2020], https://cutt.ly/smDHoGG.

Wang Jiaxin (2001a), Wang Jiaxin: xie yu 'Xianhua Guangchang' [Pisane na Campo di Fiori], Poemchina [dostęp: 5 września 202o], https://tinyurl.com/k57my3ys.

Wang Jiaxin (2001b), Ciyu [Stowa], w: 20 shiji Zhongguo wenxue zuopinxuan - shige juan [Wybór dziet chińskiej literatury $\mathrm{xx}$ wieku], red. Cao Wenxuan, Beijing Daxue Chubanshe, Pekin, s. 276-283.

Wang Jiaxin (2007), Zai shige de mudu xia [W świadectwie poezji], „Zhongguo Nanfang Yishu” [„Sztuka Południowochińska”, [dostęp: 5 września 2020], https://tinyurl.com/ 3 f49xsen.

Wang Jiaxin (2011), Traveling Poetry and the Presence of Soul: An Interview with Wang Jiaxin, „Chinese Literature Today”, vol. 2, nr 1, s. 78-82.

Wang Jiaxin (2017), Jiao wo linghun gechang de dashi [Mistrz, który nauczyt moją duszęśpiewać], Renmin Wenxue Chubanshe, Pekin.

Wang Jiaxin (2020), Duyi shigao - Wang Jiaxin: Runnian zhi shi (liu shou) [Rękopisy z epidemii - Wang Jiaxin: Wiersze z roku przestępnego (6 wierszy)], Xingcunzhe shikan [Ocaleni], [dostęp: 5 września 2020], https://tinyurl.com/x89rwcup.

Wang Junhu (2018), Menglong shi daibiao renwu yu lao yi dai ren guanxi tanwei [Relacje między Poetami Mglistymi a poetami starszych pokoleń], „Jiangsu Shifan Daxue Xuebao (Zhexue shehui kexue ban)” [„Czasopismo Uniwersytetu Nauczycielskiego Prowincji Jiangsu (Filozofia i Nauki Społeczne)”], z. 2 (43), s. 79-86. 
Wang Yin (2006), Wo kanjian le baisede Bolan [Widziatem biata Polskę], „Yiwen” („Przekłady”), z. 4, [pierwodruk], [dostęp: 5 września 202o], https://tinyurl.com/4aconfb, [wydanie internetowe].

Wukongwenda (2020), [dostęp: 5 września 2020], https://tinyurl.com/57rngmzx.

Xi Chuan (2014), Miwoshi ling yi ge Ouzhou [Inna Europa Miłosza], w: Czesław Miłosz, Miwoshi Cidian [Abecadło Miłosza], Guanxi Shifan Daxue Chubanshe, Guilin.

Xiong Hui (2016), Miwoshi zai Zhongguo de yijie licheng [Proces tłumaczenia i prezentacji dzieł Miłosza w Chinach], Xinwenwang, [dostęp: 5 września 2020], https://tinyurl.com/tyaa97y8.

Xiong Hui i Lu Beibei (2020), Miwoshi zai Zhongguo jieshou yu xingxiang bianqian [Recepcja Miłosza i ewolucja jego wizerunku w Chinach], „Lanzhou Daxue Xuebao” [„Czasopismo Uniwersytetu Prowincji Lanzhou"], z. 3, s. 20-26.

Yi Sha i Lao G (2013), Dang ni lao le: Shijie mingshi 100 shou xin yi [Kiedy jesteś stary: nowe przekłady stu stynnych wierszy], Qinghai Renmin Chubanshe, Xining.

Zhang Shuguang (2009), Miwoshi: wange de gezhe [Miłosz-śpiewak elegii], [dostęp: 5 września 2020], https://tinyurl.com/35knw8x5.

Joanna Krenz

\section{Adoptive Father: Czesław Miłosz in China}

Czesław Miłosz remains among the most important foreign authors and literary authorities for Chinese poets. Initially received in China with distrust and uncertainty, then portrayed in the official state discourse of romantic-revolutionary literature as the bard of socialism, Miłosz became the spiritual father of the younger generation affected by the Cultural Revolution and Tiananmen Square Massacre, a witness of the age, and a symbol of intellectual independence and resistance against totalitarianism. After a period of reading Miłosz in terms of ethical and political categories, Chinese reviews and literary texts in the 2010 s and 2020 s increasingly refer to Miłosz as philosophical and metaphysical poet. This article analyses Miłosz's reception in China, paying attention to the historical, cultural, and linguistic factors that shaped the assimilation of his work and the values he brought to Chinese poetry.

Keywords: contemporary Chinese poetry; Czesław Miłosz; literary translation; cross-cultural dialogue. 
Joanna Krenz - adiunkt, obecnie realizuje staż postdoktorski na Uniwersytecie Zuryskim. Tłumaczka i badaczka literatury chińskiej. Jej zainteresowania naukowe koncentrują się wokół literatury współczesnej, w tym zwłaszcza najnowszej poezji chińskiej, w perspektywie komparatystycznej w ujęciu interkulturowym i interdyscyplinarnym, a także wokół związków między literaturą a naukami ścisłymi oraz technologią. 
